\title{
Assessing the Co-Movements between Electricity Use and Carbon Emissions in the GCC area: Evidence from a Wavelet Coherence Method
}

\author{
Ali Matar ( $\sim$ amatar@jadara.edu.jo ) \\ Jadara University https://orcid.org/0000-0003-0599-5855 \\ Zeeshan Fareed
}

Huzhou University

Cosimo Magazzino

Roma Tre University: Universita degli Studi Roma Tre

Mahmoud Al-Rdaydeh

Ibn Rushd College for Management Sciences

Nicolas Schneider

The London School of Economics and Political Science Department of Law

\section{Research Article}

Keywords: Economic growth, $\mathrm{CO} 2$ emissions, electricity consumption, urbanization, trade, GCC countries, Wavelet Analysis

Posted Date: December 20th, 2021

DOI: https://doi.org/10.21203/rs.3.rs-1095996/v1

License: (c) (i) This work is licensed under a Creative Commons Attribution 4.0 International License. Read Full License 


\title{
Assessing the Co-Movements between Electricity Use and Carbon Emissions in the GCC area: Evidence from a Wavelet Coherence Method
}

\author{
Ali Matar ${ }^{*}$ \\ Jadara University, Jordan, amatar@jadara.edu.j \\ Zeeshan Fareed $^{2}$ \\ Huzhou University, China, zeeshanfareed@hotmail.com \\ Cosimo Magazzino ${ }^{3}$ \\ Roma Tre University, Italy, cosimo.magazzino@uniroma3.it
}

Mahmoud Al-Rdaydeh ${ }^{4}$

Ibn Rushd College for Management Sciences, Saudi Arabia, m.alrday-

deh@ibnrushd.edu.sa

Nicolas Schneider 5

The London School of Economics and Political Science, United Kingdom, Nicolas.Schneider@etu.univ-parisl.fr

${ }^{*}$ Corresponding author: Dean of scientific research, Associate Professor in Finance, Jadara University, Irbid-Jordan.

\begin{abstract}
This paper investigates the association between $\mathrm{CO}_{2}$ emissions and a range of factors, including electricity consumption, economic growth, urbanization, and trade openness for six Gulf Cooperation Council (GCC) countries using data covering the 1965-2019 period. Namely, Oman, Saudi Arabia, the UAE, Kuwait, Bahrain, and Qatar. Contrasting with the standard literature, our empirical strategy uses the wavelet coherence approach on the frequency domain, thought to complement the time-series econometric procedures reported on this topic. Supplied at the country-level, associated evidence presents far-reaching policy recommendations whose applications may directly benefit environmental planning and bring high information value for the sake of sustainable energies in the Gulf region.
\end{abstract}

Keywords: Economic growth; $\mathrm{CO}_{2}$ emissions; electricity consumption; urbanization; trade; GCC countries; Wavelet Analysis.

JEL: Q43, C22, C23, E20, O44. 


\section{Introduction}

Climate change has arisen as a major concern to be addressed. According to the Intergovernmental Panel on Climate Change (IPCC, 2014, 2021), the global surface temperature is expected to increase by $4.8^{\circ} \mathrm{C}$, which would induce a $0.82 \mathrm{~m}$ sea level to rise by 2100 . Indeed, a $2{ }^{\circ} \mathrm{C}$ increase in temperature would potentially threaten half of the world's population living in coastal areas (Lau et al., 2009). This problem is largely attributable to the release of harmful pollutants by anthropogenic activities. Indeed, while the atmospheric $\mathrm{CO}_{2}$ content reached in 2016 the highest level in the last 800,000 years, 2015, 2016 and 2017 are yet considered the three warmest years in our history (WMO, 2017, 2018; Liu et al., 2019). Going one step further, the National Aeronautics Space Administration (NASA, 2020) provided accurate figures on this matter. It highlighted that: carbon dioxide reached 416 parts per million, the global temperature recorded a $1.8{ }^{\circ} \mathrm{C}$ increase since 1880 , the arctic ice minimum fell of $13 \%$ over the last decade, ice sheets experienced 428 billion metric tons of losses last year, and the average sea level rise reached 3.4 millimetres per year. Thus, to slow down global warming, urgent energy regulation measures are required (Zhang et al., 2011; Schneider, 2020). For this reason, researchers have shown a keen interest to further understanding the nature of the channels connecting electricity consumption to economic growth and environmental degradations (Lean and Smyth, 2010; Cowan et al., 2014; Shahbaz et al., 2014), especially these very recent years (Al-Mulali and Che Sab, 2018; Kahouli, 2018; Salahuddin et al., 2018; Njoke et al., 2019; Salahuddin and Gow, 2019).

This study empirically investigates this nexus and considers a sample of six Gulf Cooperation Council (GCC) countries as an illustrative case. Despite abundant renewable energy resources, these economies have recorded fast economic growth over the last decades, mainly because of their important resource extraction and fossil fuels rents (natural gas and oil) (Salahuddin et al., 2015; Magazzino, 2016; Bekhet et al., 2017). At the aggregate level, these countries encompass $40 \%$ and $25 \%$ of the global oil and natural gas reserves, respectively (Salahuddin et al., 2015). Having important electricity-based fossil fuels infrastructures, the structure of GCC economies have early shifted towards a highly carbon-intensive pattern, leading them to cover $8 \%$ of world carbon release in the current times (Al-Saleh et al., 2012). It is thus obvious that the levels of per capita carbon emissions recorded it is now critical and call for major regulations to turn these oil exports-based economies towards a sustainable path (Hertog and Luciani, 2009). The Climate Change Performance Index (CCPI) 2013 Report is a relevant metric to measure this rising environmental pressure. Based on an international survey covering 58 economies responsible for $90 \%$ of world $\mathrm{CO}_{2}$ emissions from fuel combustion, Iran and Saudi Arabia were ranked second to last (respectively) for their weak climate protection performance (Germanwatch, 2017; Magazzino, 2016). Accordingly, the nature of the electricity generated and the way consumed stand at the heart of the environmental crisis and the core of solutions. For this reason, one has witnessed the multiplication of commitments to sustainability in the area, and notably through national climate plans and regulatory frameworks (Salahuddin et al., 2015). 
Yet, GCC countries share commonalities in their political, economic, and environmental conditions and differ in their national plans' features. While Saudi Arabia follows a long-term national strategy that aims to enhance employment levels and lower the heavy dependence of its economy on oil, the UAE seeks to develop its business sector, attract foreign investors, and strengthen synergies between competitive industries and emerging services. In Saudi Arabia, the employment to population ratio (15+) stagnated at 52.5\% in 2018, whereas net Foreign Direct Investments inflows did not overcome $0.6 \%$ of GDP for the same year (WDI, 2020). Regarding the UAE, a set of regulatory frameworks is currently discussed and comprises a panel devoted to enhancing Research and Development (R\&D) in the most energy-intensive sectors. In fact, $\mathrm{CO}_{2}$ emissions from electricity and heat production cover one-fourth of total fuel combustions, highlighting the need to develop further low-carbon and efficiency applications in the power sector (WDI, 2020). Bahrain's Vision 2030 explicitly targets the development of the private sector, learning by doing, and spillover effects among industries. Besides, the government targets enhancing the emergence of innovative environmental applications thought to lower the aggregate amount of $\mathrm{CO}_{2}$, which recorded $30750 \mathrm{kt}$ in 2018 (WDI, 2020). This contrasts with the State Vision 2035, which aims to orient the Kuwait economy towards a more regionally connected development, along with an explicit elaboration of a financial hub located in the northern Gulf. One more step but a long mile to go. In 2019, FDI inflows represented less than $1 \%$ of total GDP, whereas oil rent reached 42.1\% (WDI, 2020). Furthermore, Oman Vision 2030 does incorporate the rapid expansion of low-carbon and alternative energies by taking advantage of its natural endowment in solar and diversifying the structure of its valueadded with secondary products embedding more technologies and human capital stock than primary oil extraction. However, further efforts are needed to lower the heavy reliance on oil to fill economic development since oil rents reached $24.9 \%$ of GDP in 2019 (WDI, 2020). Besides the economic development targets, Qatar announced its desire to strengthen the role of institutions: a key advantage to attract foreign investors and influence firms' locations decisions. Among the main objectives are a more responsible oil and gas extraction plan, reinforced credibility of institutions, and stronger trade diversification. Overall, carbon emissions trends, which reached $73370 \mathrm{kt}$ in 2018, are expected to concentrate further policy reforms in this latter country (WDI, 2020).

The literature examining the linkages among energy use, income and carbon emissions only for the GCC countries appears limited and sporadic. However, we denoted empirical studies on MENA countries (Arouri et al., 2012a; Omri, 2013; Ozcan, 2013; Magazzino, 2019; Magazzino and Cerulli, 2019), Association of Petroleum Exporting Countries (APEC) countries (Soytas and Sari, 2009, Yuhai and Peng, 2011; Magazzino, 2017a), or large panel of middle and high-income countries (Narayan and Popp, 2012; Jaunky, 2011), indicating a systematic inclusion of all or some of the GCC countries within large heterogeneous samples. To the best of our knowledge, Salahuddin and Gow (2014) is the first study that filled this empirical gap, followed by Magazzino (2016) and Bekhet et al. (2017). Nevertheless, a thorough review of the literature underlines that only one empirical examination has considered electricity consumption for that case (i.e., Salahuddin et al., 2015). In addition, none of these papers included urbanization and trade openness data. Despite ambiguous evidence regarding 
the sign of the effect of trade on environmental pollution, trade openness remains a non-negligible determinant of environmental damage (Al-Mulali and Ozturk, 2015). It has also been shown that energy consumption and urbanization can interact, notably because investments in large installed electricity capacity exert a positive effect on employment.

Our empirical approach displays a competitive edge from the majority of existing analyses on this topic. We follow Benhmad (2012, 2013) and Aslan et al. (2014) and rely on the innovative wavelet analysis. While energy-GDP or GDP-CO $\mathrm{C}_{2}$ nexus studies often employed causality techniques on the time domain (mostly panel estimations or causality tests), using spectral tools is thought to make a bridge toward the frequency domain analysis (Kristjanpoller et al., 2018). Initiated by Ramsey and Lampart (1998a, 1998 b), this strategy can model behaviour patterns for various time horizons by testing the causality of each time scale with the pertinent ones of the other series (Aslan et al., 2014; Kristjanpoller et al., 2018). Nevertheless, the use of the wavelet technique to assess the causality assumption among energy and income variables remains relatively recent (Kristjanpoller et al., 2018). To the best of our knowledge, only three empirical studies applied this original method to deal with this nexus: Cifter and Ozun (2007) on Turkey; Aslan et al. (2014) for the United States (US); and Ha et al. (2018) for China. Overall, one must admit that none of these wavelet-based studies included $\mathrm{CO}_{2}$ emissions data, indicating a critical gap in the literature.

Calling for further empirical assessments on this topic, this paper aims to perform an in-depth investigation on GCC countries: a case study facing burning energy and environmental challenges. This research seeks to fill the gaps mentioned above by extending the literature in two distinct manners: empirically and methodologically.

- From an empirical standpoint, this study is the first to include electricity consumption data and $\mathrm{CO}_{2}$ emissions series within a multivariate framework incorporating urbanization and trade openness, and for the specific case of the GCC countries. Indeed, linking electricity-specific insights with pollution trends is thought to overcome the standard literature, which focuses on aggregate energy consumption indicators.

- From a methodological standpoint, this paper contrasts to previous ones as it adopts an innovative wavelet spectral coherence approach. As a matter of fact, a strand of the domain has systematically relied on econometric tools in the time domain. However, empirical methods differ and empirical results often conflict. Enabling the supply of estimates in the frequency domain may check the consistency of past estimates, reconciling and extending the reliability of previous studies.

- Finally, this research displays a last competitive edge as it exploits the most recent and available data series on this topic (1965-2019). It is thought to offer accurate findings and a set of updated policy recommendations for the Gulf area.

In sum, this paper investigates the empirical relationships among electricity consumption, GDP, urbanization, trade openness, and $\mathrm{CO}_{2}$ emissions for six GCC countries. A spectral Wavelet coherence approach is adopted using data series spanning the 1965- 
2019 period based on a multivariate time-series framework. Being of central importance in growth theory, we think that further examining the electricity-growth-pollution nexus in the Gulf region can bring high information value for policy purposes.

Besides the first Section, this paper is organized as follows. Section 2 offers an analysis of the trends of energy consumption and $\mathrm{CO}_{2}$ emissions in the GCC countries. Section 3 outlines the most relevant and recent literature on this topic. Section 4 introduces the data collection and describes the methodology employed. Section 5 presents and discusses the results. Finally, Section 6 presents concluding remarks and policy recommendations.

\section{Trends of energy consumption and $\mathrm{CO}_{2}$ emissions in the GCC countries}

The GCC area is characterized by burning energy and environmental issues. Looking at aggregate data from 1990 to 2018, all members experienced dramatic rises in their total final consumption (oil, natural gas and electricity combined). Namely, from 1843 to 23442 kilo tons of oil equivalent (ktoe) (Oman), from 39165 to 147304 ktoe (Saudi Arabia), from 16192 to 57783 ktoe (UAE), from 3945 to 17323 ktoe (Kuwait), from 2094 to 6618 ktoe (Bahrain), and from 3773 to 21142 ktoe (Qatar). Controlling for the size of the population, the total energy supply per capita of Oman, Saudi Arabia, the UAE, Kuwait, Bahrain, and Qatar have reached 5.3, 6.3, 7.1, 8.2, 9.1, 15.6 tons of oil equivalent per capita in 2018 (IEA, 2020).

Within this dynamic, one sees the critical role played by power needs, which have triggered the energy security issues for the entire area. Indeed, since 1971, the average growth rate of electricity consumption per capita has reached $6.2 \%$ in GCC countries (Osman et al., 2016). Systematically, the industrial and residential sectors emerge at the data two major electricity consuming topics (IEA, 2020). At the country level, Oman generated $36537 \mathrm{GWh}$ of electricity based on natural gas in 2018, which sharply overcomes the $1130 \mathrm{GWh}$ covered by solar PV for the same year (IEA, 2020). In Saudi Arabia, natural gas and oil remain at the core of power production as they generated $218470 \mathrm{GWh}$ and $159528 \mathrm{GWh}$ of electricity in 2018, respectively (IEA, 2020). A similar observation can be drawn for the UAE as electricity generation based natural gas, solar and wind represented $133739 \mathrm{GWh}, 1070 \mathrm{GWh}$, and $1 \mathrm{GWh}$, respectively (IEA, 2020). Finally, natural gas supplied 47913 GWh, 43412 GWh, 29544 GWh of electricity for Qatar, Kuwait, and Bahrain, respectively (IEA, 2020). By contrast, solar PV reached $66 \mathrm{GWh}$ for Kuwait only for the same year (IEA, 2020).

In consequence, $\mathrm{CO}_{2}$ emissions have been recording a dramatic rise for the past three decades. Over the 1990-2018 period, $\mathrm{CO}_{2}$ emissions in Oman and Saudi Arabia increased from 10.2 Mt to 68.8 Mt, and from 15.1 Mt to 491.7 Mt (IEA, 2020), which is equivalent to a $574 \%$ rise for the former, and a $3156 \%$ increase for the latter. Regarding the UAE and Kuwait, similar linear trends are observed: from 1990 to 2018, the yearly absolute release of carbon emissions translated from 51.9 Mt to $192.5 \mathrm{Mt}$ and from 27.6 Mt to 87.8 Mt, respectively (IEA, 2021). For Bahrain, a switch from 10.7 Mt to 30.2 Mt has been recorded over the same period, while Qatar displays a 601 $\%$ rise, from $12.4 \mathrm{Mt}$ to $87 \mathrm{Mt}$ (IEA, 2021).

GCC countries have recently started implementing conservation policies that aim 
to reduce the absolute amount of energy consumed (Alkhars et al., 2020). For instance, Saudi Arabia is currently undergoing a massive plan to curb carbon emissions from fuel combustion while reducing energy poverty. It involves the Clean Development Mechanism Designated National Authority, the Saudi Energy Efficiency Center, and the King Abdullah City for Atomic and Renewable Energy. In the same vein, the Supreme Council of Energy in UAE was launched in 2009 with the explicit ambition to supply policy frameworks for green energy development. By the end 2021, a wind power plant generating $50 \mathrm{MW}$ should start operating, whereas the Barakah nuclear plant (5600 MW) already began to generate power last year (Murdock et al., 2018). Similarly, the Kuwait Institute of Scientific Research (KISR) follows a similar objective as it consists in designing energy efficiency schemes with a specific focus on the construction sector (Kuwait Energy Outlook, 2016). Finally, Qatar's First National Development Strategy (2011-2016) incorporated early energy efficiency targets in the power sector. Overall, the government of Bahrain has recently adopted the "National Energy Efficiency Action Plan" and the "National Renewable Energy Action Plan" to enhance collaborative partnerships, technological diffusions and environmental efforts across the various stakeholders of the economy.

Regarding renewables, all countries recently engaged in major low-carbon energy deployments. However, since their power sectors have long been carbon-intensive, further efforts should complement these promising commitments. For instance, Saudi Arabia seeks to reach $54 \mathrm{GW}$ of decarbonized electricity generation by 2040 , which is in line with Kuwait and Oman as they both committed to cover $15 \%$ and $30 \%$ of the total electricity supply with renewable energies by 2030, respectively. The UAE recently achieved $44 \%$ of decarbonized electricity by 2050 whereas Qatar committed to reaching $360 \mathrm{MW}$ of non-fossil fuel energy generation by 2030 (Al-Badi and Almubarak, 2019).

\section{Literature Review}

The relationship among energy consumption, carbon dioxide emissions, and GDP links together the literature on the Environmental Kuznets Curve (EKC) and that on the energy use-income nexus (Kuznets, 1955). Magazzino (2016a; 2016b; 2017; 2019) and Magazzino and Cerulli (2019) have summarised these strands of economic literature. This literature survey focuses on the Gulf Cooperation Council countries (GCC) studies or on research works including the GCC countries within larger samples. First, we review the relevant energy-GDP nexus studies (3.1.). Second, we describe the empirical literature on the linkages between economic growth and pollution (3.2.). Third, previous works tackling the causal linkage between energy use, economic growth and environmental pollution in a single analysis are displayed (3.3.). Fourth, we present the few GCC countries papers, which included electricity consumption data within their framework (3.4.). Overall, we identify the key gaps in the literature and the novelty aspects this study offers (3.5.)

\subsection{Studies on the relationship between energy or electricity consumption and GDP}


Since the pioneer study initiated by Kraft and Kraft (1978) regarding the empirical energy-growth nexus, this relationship has been abundantly examined. While some empirical works have confirmed the main hypotheses associated with the energy-GDP nexus, others have denied it (i.e., growth, conservation, feedback, or neutral). Using various methodologies for different countries, results sometimes conflict. First, we focus on studies that used total energy consumption variables and turned to those which relied on electricity consumption data. The "conservation hypothesis" has been confirmed in Al-Iriani (2006) for the GCC countries; Mehrara (2007) for 11 Oil Exporting Countries (OEC) (including Iran, Kuwait, and Saudi Arabia); Huang et al. (2008) for middle- and high-income countries (including Oman and Saudi Arabia in a sample of 82 economies); Narayan and Popp (2012) for four of the 12 MENA countries (including Saudi Arabia, UAE, Bahrain, Kuwait, Oman, but also Qatar). By contrast, the "growth hypothesis" has been confirmed by Mahadevan and Asafu-Adjaye (2007) when considering 20 energy importers and exporters (including Kuwait and Saudi Arabia).

Focusing on a disaggregate energy source (i.e., electricity consumption), a range of studies validated the "feedback hypothesis": Squalli (2007) for 11 Organization of the Petroleum Exporting Countries (OPEC) (including Kuwait, Qatar, Saudi Arabia, and UAE); Narayan and Smyth (2009) for 6 MENA countries (including Kuwait, Oman and Saudi Arabia); Hamdi et al. (2014) for Bahrain; Osman et al. (2016) for the GCC countries. For an exhaustive overview of energy-growth and electricity-growth nexus papers, see Ozturk (2010). Additionally, a comprehensive international survey on country-specific studies can be found in Omri (2014).

\subsection{Studies on the relationship between $\mathrm{CO}_{2}$ emissions and GDP}

Since the seminal study established by Grossman and Krueger (1994), the Environmental Kuznets Curve (EKC) has been the subject of extensive investigations and for a huge number of countries, sometimes leading to opposite findings (Selden and Song, 1994; Stern et al., 1996; Dinda and Coondoo, 2006; Galeotti et al., 2006; Acaravci and Ozturk, 2010; Omri and Nguyen, 2014). However, most EKC studies focused on Asian and Latin American economies (Al-Rawashdeh et al.; 2014). Arouri et al. (2012b) noticed that until 2010, less attention was given to other emerging countries, especially in the MENA region and thus in the Gulf area. One observes from related literature that EKC has been verified in numerous empirical works: Narayan and Narayan (2010) for Kuwait, Qatar, and the UAE upon 43 developing countries; Basarir and Arman (2014) for the UAE, Saudi Arabia, and Bahrain. Inversely, EKC has been rejected by several studies: Jaunky (2011) for 36 high-income economies (including Oman, the UAE and Bahrain); Arouri et al. (2012a) for 12 MENA economies (including the 6 GCC countries); Al-Rawashdeh et al. (2014) for 22 MENA states (including the 6 GCC countries).

3.3 Studies on the relationship among energy consumption, $\mathrm{CO}_{2}$ emissions, and GDP 
Regarding the third strand of the literature, a range of empirical assessments have been performed on the energy-growth-carbon emissions nexus (Al-Mulali (2012) for different economic regions; Saboori et al. (2014) for OECD economies; Cowan et al. (2014) for BRICS countries). Not with standing, single examinations focusing only on the GCC countries are still less frequent than others, despite growing attention reported these recent years (Al-Mulali and Tang, 2013).

Above all, the "growth hypothesis" has been confirmed in Alkhathlan and Javid (2013) for Saudi Arabia. The authors used the Granger causality (Granger, 1969) test from 1980-2011. Such a conclusion aligns with the multi-country analysis performed by Magazzino (2016b). By contrast, the "conservation hypothesis" has been abundantly validated. Using a VECM, Farhani et al. (2013) supported the existence of a unidirectional causal relationship running from GDP growth to energy use for the whole MENA sample. This corroborates Ozcan (2013) findings, who applied short and long-run causality tests (Engle and Granger, 1987) over the period 1990-2008 and confirmed the "conservation hypothesis" for 12 MENA countries (including Oman, Bahrain, the UAE and Saudi Arabia). This echoes Salahuddin and Gow (2014), who used panel cointegration and panel Granger causality techniques over 1980-2012 and found unidirectional causality from GDP to energy use. Furthermore, Magazzino (2016a) collected data for 10 MENA economies from 1971 to 2006. The Panel Vector Auto-Regressive (PVAR) model displayed a negative response of GDP to shock in $\mathrm{CO}_{2}$ for the six GCC countries and claimed that real GDP is a central determinant of energy use and $\mathrm{CO}_{2}$ emissions. In Bekhet et al. (2017), the authors employed ARDL and VECM frameworks using data from 1980 to 2011 and stressed the existence of long-run causality from $\mathrm{CO}_{2}$ emissions, financial development, and GDP to energy use in GCC countries. The "feedback hypothesis" has been validated in Omri (2013) for 14 MENA countries and using a GMM on a Cobb-Douglas production function over the period 1990-2011. Similarly, Asif et al. (2015) used the FMOLS and DOLS estimations methods over the 1980-2011 period, they concluded that urbanization, growth, and energy use are positively associated with carbon emissions for the whole sample. Regarding the "neutral hypothesis", Sari and Soytas (2009) considered a sample of 5 OPEC countries (including Saudi Arabia) and applied the ARDL approach over the period 1971-2002. Results fail to supply evidence of significant causal link among variables, which is in line with Hamdi and Sbia (2014a), who ended up to the same conclusion for GCC using VECM over the 1980-2009 period. More recently, Magazzino and Cerulli (2019) applied a Responsiveness Scores (RS) approach on 17 MENA countries with data spanning the 1971-2013 period. Empirical results demonstrated that energy use showed positive RSs to shock in per capita GDP and vice versa. Inversely, trade and urban population showed negative responses. Lastly, recent evidence on this nexus for GCC countries can be found in Zmami and Ben-Salha (2020), Alkhars et al. (2020), Baydoun and Aga (2021); and Majeed et al. (2021). Table 1 outlines the key information on this literature.

Table 1. Summary of previous studies on energy consumption, $\mathrm{CO}_{2}$ emissions, and GDP for GCC countries.

\begin{tabular}{|c|c|c|c|c|c|}
\hline Author(s) & Countries & Period & Methodology & Variables & Causality \\
\hline
\end{tabular}




\begin{tabular}{|c|c|c|c|c|c|}
\hline $\begin{array}{l}\text { Sari and } \\
\text { Soytas } \\
(2009)\end{array}$ & $\begin{array}{l}5 \text { OPEC } \\
\text { countries }\end{array}$ & $1971-2002$ & ARDL & $\begin{array}{l}\text { Energy consumption, } \\
\text { GDP, and } \mathrm{CO}_{2} \text { emis- } \\
\text { sions, employment }\end{array}$ & $\mathrm{E} \Leftrightarrow \mathrm{Y}$ and $\mathrm{Y} \Leftrightarrow \mathrm{C}$ \\
\hline $\begin{array}{l}\text { Alkhathlan } \\
\text { and Javid } \\
\text { (2013) }\end{array}$ & $\begin{array}{l}\text { Saudi Ara- } \\
\text { bia }\end{array}$ & $1980-2011$ & GC & $\begin{array}{l}\text { GDP, } \mathrm{CO}_{2} \text { emissions } \\
\text { per capita and energy } \\
\text { consumption per capita }\end{array}$ & $\mathrm{E} \rightarrow \mathrm{Y}$ and $\mathrm{Y} \rightarrow \mathrm{C}$ \\
\hline $\begin{array}{l}\text { Farhani } \text { et } \\
\text { al. }(2013)\end{array}$ & $\begin{array}{l}11 \text { MENA } \\
\text { countries }\end{array}$ & 1980-2009 & VECM & $\begin{array}{l}\text { Energy consumption, } \\
\mathrm{GDP} \text {, and } \mathrm{CO}_{2} \text { emis- } \\
\text { sions }\end{array}$ & $\begin{array}{c}\mathrm{E} \rightarrow \mathrm{Y} \text { and } \mathrm{E}, \\
\mathrm{Y} \rightarrow \mathrm{C}\end{array}$ \\
\hline $\begin{array}{l}\text { Omri } \\
(2013)\end{array}$ & $\begin{array}{l}14 \text { MENA } \\
\text { countries }\end{array}$ & $1990-2011$ & GMM & $\begin{array}{c}\text { Energy consumption, } \\
\text { GDP, and } \mathrm{CO}_{2} \text { emis- } \\
\text { sions }\end{array}$ & $\mathrm{E} \leftrightarrow \mathrm{Y}$ and $\mathrm{E} \rightarrow \mathrm{C}$ \\
\hline $\begin{array}{l}\text { Ozcan } \\
(2013)\end{array}$ & $\begin{array}{l}12 \text { MENA } \\
\text { countries }\end{array}$ & $1990-2008$ & VECM & $\begin{array}{l}\text { Energy consumption, } \\
\text { GDP, and } \mathrm{CO}_{2} \text { emis- } \\
\text { sions }\end{array}$ & $\mathrm{Y} \rightarrow \mathrm{E}$ \\
\hline $\begin{array}{l}\text { Hamdi and } \\
\text { Sbia } \\
(2014 a)\end{array}$ & $\begin{array}{l}\text { GCC coun- } \\
\text { tries }\end{array}$ & 1980-2009 & VECM & $\begin{array}{l}\text { Energy consumption, } \\
\text { GDP, and } \mathrm{CO}_{2} \text { emis- } \\
\text { sions }\end{array}$ & $\mathrm{E} \nRightarrow \mathrm{Y}$ \\
\hline $\begin{array}{l}\text { Salahuddin } \\
\text { and Gow } \\
(2014)\end{array}$ & $\begin{array}{l}\text { GCC coun- } \\
\text { tries }\end{array}$ & $1980-2012$ & GC & $\begin{array}{c}\text { Energy consumption, } \\
\text { GDP, and } \mathrm{CO}_{2} \text { emis- } \\
\text { sions }\end{array}$ & $\mathrm{Y} \rightarrow \mathrm{E}$ \\
\hline $\begin{array}{l}\text { Asif } \text { et al. } \\
\quad(2015)\end{array}$ & $\begin{array}{l}\text { GCC coun- } \\
\text { tries }\end{array}$ & $1980-2011$ & $\begin{array}{c}\text { FMOLS, } \\
\text { DOLS, DHC }\end{array}$ & $\begin{array}{l}\text { Energy consumption, } \\
\text { GDP, and } \mathrm{CO}_{2} \text { emis- } \\
\text { sions, urbanization }\end{array}$ & $\begin{array}{l}\mathrm{E}, \mathrm{Y}, \mathrm{U} \rightarrow \mathrm{C} \mathrm{E} \leftrightarrow \mathrm{Y} \\
\text { (for Oman and the } \\
\text { UAE) }\end{array}$ \\
\hline $\begin{array}{l}\text { Magazzino } \\
(2016 a)\end{array}$ & $\begin{array}{l}10 \text { MENA } \\
\text { countries }\end{array}$ & $1971-2006$ & VAR, IRF & $\begin{array}{l}\text { Energy consumption, } \\
\text { GDP, and } \mathrm{CO}_{2} \text { emis- } \\
\text { sions }\end{array}$ & $\mathrm{Y} \rightarrow \mathrm{E}, \mathrm{C}$ \\
\hline $\begin{array}{l}\text { Magazzino } \\
(2016 b)\end{array}$ & $\begin{array}{c}6 \mathrm{GCC} \\
\text { countries }\end{array}$ & $1960-2013$ & GC & $\begin{array}{l}\text { Energy consumption, } \\
\text { GDP, and } \mathrm{CO}_{2} \text { emis- } \\
\text { sions }\end{array}$ & $\begin{array}{c}\mathrm{E} \rightarrow \mathrm{Y} \text { (for } \mathrm{Ku}- \\
\text { wait, Oman, and } \\
\text { Qatar) }\end{array}$ \\
\hline $\begin{array}{l}\text { Bekhet et } \\
\text { al. }(2017)\end{array}$ & $\begin{array}{l}\text { GCC coun- } \\
\text { tries }\end{array}$ & $1980-2011$ & $\begin{array}{l}\text { ARDL, } \\
\text { VECM }\end{array}$ & $\begin{array}{c}\text { Energy consumption, } \\
\mathrm{GDP} \text {, and } \mathrm{CO}_{2} \text { emis- } \\
\text { sions, financial devel- } \\
\text { opment }\end{array}$ & $\begin{array}{l}\mathrm{Y} \rightarrow \mathrm{E} \text { (except the } \\
\mathrm{UAE} \text { ) and } \mathrm{C} \rightarrow \mathrm{E} \\
\text { (for Saudi Arabia, } \\
\text { the UAE, and Qa- } \\
\text { tar) }\end{array}$ \\
\hline $\begin{array}{l}\text { Magazzino } \\
\text { and Cerulli } \\
\quad(2019)\end{array}$ & $\begin{array}{l}17 \text { MENA } \\
\text { countries }\end{array}$ & $1971-2013$ & RS approach & $\begin{array}{c}\text { Energy consumption } \\
\text { per capita, GDP, and } \\
\mathrm{CO}_{2} \text { emissions per cap- } \\
\text { ita, urban population, } \\
\text { trade }\end{array}$ & - \\
\hline $\begin{array}{l}\text { Zmami and } \\
\text { Ben-Salha } \\
(2020)\end{array}$ & $\begin{array}{l}\text { GCC coun- } \\
\text { tries }\end{array}$ & $1980-2017$ & $\begin{array}{l}\text { PMG-ARDL, } \\
\text { STIRPAT }\end{array}$ & $\begin{array}{l}\text { per capita GDP, } \\
\text { energy consumption, } \\
\text { urbanization, } \\
\text { international trade and } \\
\text { foreign direct invest- } \\
\text { ments, and CO2 } \\
\text { emissions }\end{array}$ & $\mathrm{Y}, \mathrm{FDI}, \mathrm{E} \rightarrow \mathrm{C}$ \\
\hline $\begin{array}{l}\text { Alkhars et } \\
\text { al. }(2020)\end{array}$ & $\begin{array}{l}\text { GCC coun- } \\
\text { tries }\end{array}$ & 2006-2019 & $\begin{array}{l}\text { Meta-Analy- } \\
\text { sis }\end{array}$ & $\begin{array}{l}\text { Energy consumption } \\
\text { and economic growth }\end{array}$ & $\begin{array}{c}\mathrm{E} \leftrightarrow \mathrm{Y} \text { (for } 43 \% \text { of } \\
\text { the sample) }\end{array}$ \\
\hline $\begin{array}{l}\text { Baydoun } \\
\text { and Aga } \\
\text { 2021) }\end{array}$ & $\begin{array}{l}\text { GCC coun- } \\
\text { tries }\end{array}$ & $1995-2018$ & $\begin{array}{l}\text { CS-ARDL, } \\
\text { DHC }\end{array}$ & $\begin{array}{l}\text { energy consumption, } \\
\text { economic growth, fi- } \\
\text { nancial development, } \\
\text { and globalization and } \\
\quad \mathrm{CO}_{2} \text { emissions }\end{array}$ & $\mathrm{Y}, \mathrm{E} \rightarrow \mathrm{C}$ \\
\hline $\begin{array}{l}\text { Majeed } \text { et } \\
\text { al. }(2021)\end{array}$ & $\begin{array}{l}\text { GCC coun- } \\
\text { tries }\end{array}$ & $1990-2018$ & CS-ARDL & $\begin{array}{l}\text { Disaggregated Energy } \\
\text { consumption, natural }\end{array}$ & $\mathrm{NRA}, \mathrm{U}, \mathrm{Y}, \mathrm{E} \rightarrow \mathrm{C}$ \\
\hline
\end{tabular}


resources, GDP and

$\mathrm{CO} 2$ emissions

Source: our elaborations.

Notes: Y, E, C, NRA, FDI, and U represent economic growth, energy consumption, $\mathrm{CO}_{2}$ emissions, natural resource abundance, Foreign Direct Investments, and urbanization, respectively. $\mathrm{E} \rightarrow \mathrm{Y}$ indicates a unidirectional causal relationship from energy consumption to economic growth. $\mathrm{Y} \rightarrow \mathrm{C}$ indicates a unidirectional causal relationship from economic growth to energy consumption. $\mathrm{E} \rightarrow \mathrm{C}$ indicates a unidirectional causal relationship from energy consumption to $\mathrm{CO}_{2}$ emissions. $\mathrm{C} \rightarrow \mathrm{E}$ indicates a unidirectional causality running from $\mathrm{CO}_{2}$ emissions to energy consumption. $\mathrm{E} \nRightarrow \mathrm{Y}$ indicates non-causal link between energy consumption and economic growth. $\mathrm{Y} \Leftrightarrow \mathrm{C}$ indicates no causal link between economic growth and $\mathrm{CO}_{2}$ emissions. ARDL: Auto-Regressive Distributed Lag; GC: Granger Causality; VECM: Vector Error Correction Model; GMM: Generalized Method of Moments; FMOLS: Fully Modified Ordinary Least Squares; DOLS: Dynamic Ordinary Least Squares; DHC: Dumitrescu-Hurlin Causality; VAR: Vector Auto-Regressive; IRF: Impulse Response Function; RS: Responsiveness Scores; CSARDL: Cross-Sectionally Augmented ARDL. PMG-ARDL: Pooled Mean Group-ARDL. STIRPAT: Stochastic Impacts by Regression on Population, Affluence, .and Technology

\subsection{Studies on the relationship among electricity consumption, $\mathrm{CO}_{2}$ emissions, and GDP}

Studies tackling the relationship among electricity consumption, GDP and carbon emissions for the GCC countries are recent. To the best of our knowledge, we denote only two existing papers using every two different approaches. First, within a singlecountry study, Salahuddin et al. (2018) assessed the linkages among GDP, electricity use, FDI, financial development on carbon emissions for Kuwait. Applying VECM with data from 1980 to 2013, findings showed evidence of a bidirectional link between electricity use and GDP. In addition, the Granger causality test results supported the existence of a one-way causality from FDI, electricity use, and economic growth to carbon emissions. Using a multi-country approach, Salahuddin et al. (2015) explored the causal nexus among $\mathrm{CO}_{2}$ emissions, economic growth, electricity consumption and financial development for the GCC countries. The authors employed panel data analysis (i.e., DFE, FMOLS, and DOLS) with data from 1980 to 2012. As a result, a positive relationship is revealed from electricity use and growth to carbon emissions over the long run. Inversely, a negative relationship between $\mathrm{CO}_{2}$ emissions and financial development was supported. In addition, Granger causality findings provided evidence of a one-way causality from electricity use to carbon emissions and a bidirectional causal relationship between economic growth and carbon emissions. Lastly, Impulse Response Functions (IRF) and Forecast Error Variance Decomposition (FEVD) underlined that per capita electricity use and GDP would substantially influence carbon emissions trends into the future. Table 2 summarizes this literature.

Table 2. Summary of previous studies on electricity consumption, $\mathrm{CO}_{2}$ emissions, and GDP for GCC countries.

\begin{tabular}{cccccc}
\hline Author(s) & Countries & Period & $\begin{array}{c}\text { Methodol- } \\
\text { ogy }\end{array}$ & Variables & Causality \\
\hline Salahuddin & GCC coun- & $1980-2012$ & FMOLS, & GDP, electricity con- & E $\rightarrow$ C \\
et al. $(2015)$ & tries & & DOLS, DFE & $\begin{array}{c}\text { sumption, } \mathrm{CO}_{2} \text { emissions, } \\
\text { financial development }\end{array}$ & $\begin{array}{c}\text { and } \\
\text { YC }\end{array}$
\end{tabular}




\begin{tabular}{|c|c|c|c|c|c|}
\hline $\begin{array}{l}\text { Salahuddin } \\
\text { et al. (2018) }\end{array}$ & Kuwait & $1980-2013$ & VECM, GC & $\begin{array}{c}\text { GDP, electricity con- } \\
\text { sumption, } \mathrm{CO}_{2} \text { emissions, } \\
\text { FDI, financial develop- } \\
\text { ment }\end{array}$ & $\begin{array}{c}\mathrm{E} \leftrightarrow \mathrm{Y} \\
\text { and } \mathrm{F}, \mathrm{E}, \\
\mathrm{Y} \rightarrow \mathrm{C}\end{array}$ \\
\hline
\end{tabular}

Source: our elaborations.

Notes: Y, E F, and C represent economic growth, electricity consumption, FDI and $\mathrm{CO}_{2}$ emissions, respectively. $\mathrm{E} \rightarrow \mathrm{C}$ indicates a unidirectional causality running from electricity consumption to $\mathrm{CO}_{2}$ emissions. $\mathrm{Y} \leftrightarrow \mathrm{C}$ indicates a bidirectional causality between economic growth and $\mathrm{CO}_{2}$ emissions. $\mathrm{E} \leftrightarrow \mathrm{Y}$ indicates a bidirectional causality between electricity consumption and economic growth. $\mathrm{Y} \rightarrow \mathrm{C}$ indicates a unidirectional causality from economic growth to $\mathrm{CO}_{2}$ emissions. FMOLS: Fully Modified Ordinary Least Squares; DOLS: Dynamic Ordinary Least Squares; DFE: Dynamic Fixed Effect; VECM: Vector Error Correction Model; GC: Granger Causality.

\subsection{Gaps in the literature and contribution proposal}

This literature review underlines three important points. First, empirical results drawn from the study of GCC economies are conflicting. While some papers supported the existence of a causal link between energy consumption and $\mathrm{CO}_{2}$ emissions, others failed to depict it. This is due to the wide range of methodologies employed on this topic and the various periods selected. Second, we noted that Salahuddin et al. (2018) is the only published paper investigating the electricity-growth-carbon emissions nexus for the single case of six GCC economies.

Nonetheless, we must admit that the wavelet analysis remains incipient and mostly inexistent when dealing with this research question. Furthermore, despite three recent wavelet applications on various cases (Cifter and Ozun, 2007 for Turkey; Aslan et al., 2014 for the US; Ha et al., 2018 for China), none has included $\mathrm{CO}_{2}$ emissions data within its framework. Third, we believe that trade openness and urban population are non-negligible drivers of environmental pollution. Thus, we fill this lack in the literature and include these two variables as additional pollution factors.

Contributing to the literature on this topic, this paper investigates the linkages operating among electricity consumption, $\mathrm{CO}_{2}$ emissions, economic growth, urbanization, and trade openness for six Gulf Cooperation Council (GCC) countries. In contrast to traditional time series approaches, our empirical strategy uses the wavelet analysis on the frequency domain, which is thought to complement the time-series econometric procedures reported on this topic. Extending the data period to the 1965-2019 period is thought to bring updated results.

\section{Data Collection and Wavelet Framework}

We constructed a yearly dataset covering the period ${ }^{1}$ from 1965 to 2019 using the World Bank Development Indicators database. The generic function of the analyzed model can be written as:

\footnotetext{
${ }^{1}$ Some of the Gulf countries like UAE, Qatar, and Bahrain are born in 1971, 1971, and 1980, respectively. Therefore, for these countries, we performed a backcasting of all series through the backward recursive process, by using the function reverse forecast package in $\mathrm{R}$ software. This function uses ARIMA model to predict the years 1965-1970 for UAE and Qatar, and 1965-1979 for Bahrain.
} 


$$
C O_{2}=f\left(G D P_{t}, E P C_{t}, T O_{t}, U R_{t}\right)
$$

$\mathrm{CO}_{2}$ in (8) represents the per capita carbon dioxide emissions (in metric tons), GDP is the real per capita GDP (in constant 2010 US\$), EPC is the electric power consumption (in per capita $\mathrm{kWh}$ ), which represent the living standards. TO indicates trade openness (summation of the percentage of imports and exports to GDP), as proposed by Hossain (2011) and Akın (2014); UR represents the urbanization (the share of the urban population in total population).

To investigate the time-frequency dependence of the selected series, we used the wavelet coherence technique. One of the main advantages of this method is its prevention from the necessity of separating the sample into various sub-sample periods for the analysis of co-movement during the time of crisis. Moreover, the wavelet approach has numerous advantages in time series analysis; 1) We can estimate it for nonstationary data, thus relaxing the assumption of stationarity. 2) It can be estimated on any time series with a non-normal distribution. 3) It can capture asymmetric relationships between variables at different time-frequency scales. 4) Localized events in time can be efficiently captured. 5) Continuous wavelet transform (CWT) is suffered less from boundary conditions and leakages because CWT discretizes scale more finely than the discrete wavelet transform (DWT). This method may be used to determine structural breaks during the occurrence of a complete breakdown in correlation or when the relevant frequency band is shifted. However, the decision to apply the cutoff point for the segregation of times of crisis could be prevented. Consequently, the short-run and long-run causal relations between $\mathrm{CO}_{2}, E P C, G D P, U R$, and $T O$ in GCC at the same time were captured. The method of a multi-scale decomposition brings out a natural frame to illustrate frequency-dependent behavior for exploring the relationships among the variables.

Table 3 shows the descriptive statistics of these variables for all countries. For $\mathrm{CO}_{2}$ and GDP, the highest value of mean was present in Qatar. On the other hand, the lowest mean values for these two variables were present in Oman. Bahrain exhibits the highest mean of $E P C$. It is noteworthy that the negative skewness results are present in most GCC countries for EPC variable, with Oman and Saudi Arabia as exceptions. 
Table 3. Descriptive statistics.

\begin{tabular}{cccccccc}
\hline \hline Variable & Mean & Median & SD & Skewness & $\begin{array}{c}\text { Kurto- } \\
\text { sis }\end{array}$ & $\begin{array}{c}\text { Pseudo } \\
\text { SD }\end{array}$ & IQR \\
\hline PCRGDP & 10.9955 & 10.8203 & 0.4556 & 0.3959 & 2.3023 & 0.5709 & 0.7702 \\
EPC & 8.0457 & 9.1531 & 2.6808 & -1.6855 & 4.0609 & 0.8186 & 1.1040 \\
CO2E & 4.0019 & 3.3219 & 1.8056 & 1.6532 & 4.1896 & 0.7030 & 0.9483 \\
\hline \hline Country & Variable & Mean & Median & SD & Skewness & Kurtosis \\
\hline Bahrain & PCRGDP & 10.6522 & 10.6601 & 0.0503 & -0.2426 & 2.5606 \\
& EPC & 9.6763 & 9.8317 & 0.4369 & -2.1380 & 6.2182 \\
Kuwait & CO2E & 3.1791 & 3.1833 & 0.1151 & 0.0060 & 2.1051 \\
& PCRGDP & 11.0135 & 11.0550 & 0.1878 & -1.1849 & 4.4214 \\
& EPC & 9.3496 & 9.5455 & 0.3721 & -0.5667 & 1.9446 \\
Oman & CO2E & 3.1136 & 3.3004 & 0.4017 & -2.0609 & 9.0419 \\
& PCRGDP & 10.4836 & 10.5759 & 0.2179 & -1.0231 & 3.1309 \\
& EPC & 2.1627 & 1.9735 & 0.4323 & 0.3213 & 1.5826 \\
Qatar & CO2E & 7.8931 & 7.93060 & 0.6020 & -0.5990 & 2.8289 \\
& PCRGDP & 11.5822 & 11.6142 & 0.2263 & -0.3332 & 2.4351 \\
& EPC & 9.4120 & 9.4016 & 0.2086 & -0.0290 & 1.2615 \\
Saudi Arabia & CO2E & 3.8469 & 3.9242 & 0.2878 & -0.6058 & 2.2552 \\
& PCRGDP & 10.7765 & 10.7343 & 0.1764 & 2.5576 & 9.3064 \\
& EPC & 8.5058 & 8.5363 & 0.4003 & -0.4564 & 2.4454 \\
United Arab & CO2E & 2.7055 & 2.7060 & 0.1697 & -0.3548 & 2.2385 \\
Emirates & PCRGP & 11.4650 & 11.5200 & 0.2924 & -0.1457 & 2.6761 \\
& EPC & 9.1679 & 9.1893 & 0.2136 & -0.6283 & 2.5894 \\
\hline \hline
\end{tabular}

Notes: SD: Standard Deviation; IQR: Inter-Quartile Range; PSD: Pseudo Standard Deviation.

Different approaches have been applied to examine the relationship among energy economics and finance by modelling whether the co-integration, co-movement and contagions among various variables in a multivariate framework using VAR, VECM, ARDL panel data and causality models (Huang et al., 2008; Ozturk, 2010; Hamdi and Sbia, 2014; Hamdi et al., 2014; Matar, 2015, 2016; Bekhet et al., 2017; Magazzino and Cerulli, 2019). However, various researchers have implemented the wavelet approach to examine economic and financial time series. For instance, Ramsey and Lampart (1998), Torrence and Compo (1998), Grinsted et al. (2004), and Rua and Nunes (2009) suggested detailed and formal descriptions of wavelet analysis.

The current study investigates the causal relationship between $\mathrm{CO}_{2}$ emissions, electricity consumption, trade opens, urbanization, and GDP using wavelet analysis for GCC countries. With a wavelet analysis, a time series could be separated into frequency elements. While the Fourier analysis has a full ability of representation and decomposition of stationary time-series, the research could be conducted with a nonstationary time-series through wavelets. Furthermore, wavelets promote time conservation for localized information, enabling co-movement to be measured in the timefrequency space. Wavelet analysis is based on the wavelet transform, where changes occur in the signal or time series with the assistance of wavelet functions. Moreover, it plays a role as a small wave consisting of the starting and ending points. When these waves are manipulated through their accurate motion and a squeezing or stretching process, a non-stationary and complex signal could be depicted as the elements of frequency, which go through localization in time. There are many different wavelet functions, discrete and continuous. 
Rua (2010) developed a new wavelet-based measure of co-movement, which enables to examine the co-movement for frequency level and over the time domain. This novel measurement allows one to recognize the change of the degree of co-movement over frequencies and time periods. By incorporating the time dependence of the comovement, wavelet analysis introduces a more unified framework.

Basdas (2012) introduced the Wavelet Analysis as small waves that begin at a finite point in time and end at a later limited point in time. They can be seen as an extension of the Fourier analysis and control some useful properties for filtering the data to different frequencies. With this filtering, we can analyze the various return categories that model the total returns instead of analyzing the returns from various periods. Nevertheless, wavelets have been widely overlooked in finance and economics, with only a few exceptions.

Wavelet analysis is primarily time series technique, there are three methods of wavelet analysis the first method is called continues with the function $w(t)$ has two features with 0 mean and unit:

$$
\begin{aligned}
& \int_{-\infty}^{\infty} w(t) d t=0 \\
& \int_{-\infty}^{\infty}|w(t)|^{2} d t=1
\end{aligned}
$$

Following Ramsey and Lampert (1998), Rua and Nunes (2009), and Aloui and Hkiri (2014), the transform of discreet enduring wavelet analysis is given by:

$$
w^{x}(u, s)=\frac{1}{\sqrt{u}} \sum_{t=1}^{N} x(t) \psi *\left(\frac{t-s}{u}\right)
$$

where $u$ is the scale, $s$ represents the time position and $*$ denotes a complex conjugate. The main advantage of wavelet transform is the adequacy to decompose and therefore reconstruct the function $x(t)$ as follows:

$$
\left.x(t)=\frac{1}{c_{\psi}} \int_{0}^{\infty}\left[\int_{0}^{\infty} w^{x}(u, s) \psi_{u, s}(t) d u\right] \frac{d s}{s^{2}}, s\right\rangle 0
$$

The main preference of the wavelet transform is the power protection of the selected time series. This advantage is utilized for the power spectrum analysis, which specifies the variance as:

$$
\|x\|^{2}=\frac{1}{c_{\psi}} \int_{0}^{\infty}\left[\int_{-\infty}^{\infty}\left|w^{x}(u, s) \psi_{u, s}(t)\right|\right] d u \frac{d s}{s^{2}}
$$

To test the cross-correlation action among the frequency and time period, we employ the square coherence wavelet by presenting first transform of cross-wavelet following Torrence and Compo (1998) subscribe the wavelet squared coherence as the next (7) and (8) models, respectively. 


$$
w_{x y}(u, s)=w_{x}(u, s) w_{y}^{*}(u, s)
$$

The cross wavelet transform is defined of two stock index time series $y(t)$ and $x(t)$ with the enduring transforms of $w y(u, s)$ and $w x(u, s)$. Where, $\mathrm{s}$ is the scale, $\mathrm{u}$ is the position index, * refer to the compound consolidate. Finally, to examine the coherence of the cross wavelet transform in the time-frequency space, we apply the squared coherence wavelet called wavelet coherence that can be introduced as:

$$
R^{t}{ }_{t}(s)=\frac{\mid S\left(\left.s^{-1} w_{t}^{x y}(s)\right|^{2}\right.}{S\left(s^{-1}\left|w_{t}^{x}(s)\right|^{2}\right) S\left(s^{-1}\left|w_{t}^{y}(s)\right|^{2}\right.}
$$

The wavelet coherence could be considered a correlation coefficient with a value range between 0 and $1, s$ represents the smoothing parameter. In the no easing condition, the wavelet coherence will be equal 1 . Furthermore, the squared wavelet coherence coefficient is in the range $0 \leq R^{2}(u, s) \leq 1$ and values close to 0 indicate weak correlation while that close to 1 confirms the presence of high correlation. Thus, the wavelet coherence is a convenient instrument to measure the selected variables comovement over time (Aloui and Hikiri, 2014).

\section{Empirical Investigation}

Figures 1, 2, 3, and 4 show wavelet coherence analysis between $\mathrm{CO}_{2}$ and the independent variables $(E C, G D P, T O$, and $U R)$ in GCC countries. The $x$-axis in the figures indicates the time while the $y$-axis indicates the frequency. In the wavelet coherence, the decision could be taken only within the shape of a white cone line, which is called "the cone of influence". The color scale on the right side determines the strength of the correlation among the variables. Hotter colors present a higher correlation between the variables concerning $R^{2}$, and a thick black shape indicates a 5\% significance level in the figures.

As clearly seen in Figure 1, the results of wavelet coherence between $\mathrm{CO}_{2}$ and GDP are for the six GCC countries. The obtained results show a weak positive significant correlation between $\mathrm{CO}_{2}$ and GDP for Saudi Arabia. For instance, between 1975-1995, the arrows that were mostly rightward pointing in the thick black shape area confirm a positive relationship between GDP and $\mathrm{CO}_{2}$ at a high scale (16 years, long-run) in Saudi Arabia. However, during the period between 1965-1975, the results were mixed between positive and negative some time and at a low scale (3-4 years, short-run). Also, the results showed that this relationship between 1995-2010 was very weak, but it became stronger after 2010 .

On the top right of Figure 1, the results of wavelet coherence between $\mathrm{CO}_{2}$ and GDP for the UAE are shown. The overall result shows a weak positive correlation (but not significant over the whole sample period); it only shows significance until the late 90's. For instance, during the period 1965-1995, the leftward pointing arrows in the 
thick black shape area mostly supports evidence of a negative and significant relationship between GDP and $\mathrm{CO}_{2}$ at high scale (16 years, long-run); but after that, the results are positive but not significant. In Qatar and Bahrain, the situation is a bit different, since the results indicate that the relationship between $\mathrm{CO}_{2}$ and GDP is mostly uncorrelated at the high scale, while it shows some significance at a low scale, especially between the beginning of 80's till the late 90's for Qatar, and till 2016 for Bahrain, although this relationship is considered weak and unclear. The results of Kuwait show that this relationship is mostly moderated, and it is positive at a low scale (3-4 years), but not significant. At the bottom left of Figure 1, the wavelet coherence results for Oman indicate that the relationship is mostly positive and significant at low and medium scales (3-8 years). For instance, in the period 1965-1995, the correlation is significant at a low scale (3-4 years), while in the period between the late 90's till 2019, the correlation is significant and positive at a medium scale (6-8 years), where the arrows in the thick black shape area were mostly rightward pointing. The most positive effect of GDP on $\mathrm{CO}_{2}$ emission in GCC countries could be because the economies of these countries are highly dependent on oil revenues. Increasing oil prices help increase the growth output, which leads to a rise in average household income. As a result, the consumption patterns would change from low emission-intensive services and goods to more energy and emission-intensive ones. For example, oil price booms during and after the financial crisis 2007-2008 has led to an increase in the average household incomes by about 75 percent in Saudi Arabia and made the economy ranked as the world's $19^{\text {th }}$ largest economy. As a result, the country's GDP has been doubled, and 1.7 million jobs have been created. Such transforms could be responsible for the growing movement in $\mathrm{CO}_{2}$ emissions by changing citizens' lifestyles in these countries. Ultimately, the subsequent effect is the rise in the emission of pollutants such as $\mathrm{CO}_{2}$. The results of the relationship between GDP and $\mathrm{CO}_{2}$ emissions are in accordance with several previous studies (Ehigiamusoe and Lean, 2019; Bekhet et al., 2017; Farhani et al., 2013), but against the results of others (Seetanah et al., 2019; Hossain and Hasanuzzaman, 2013).

Figure 1: Wavelet coherence between $\mathrm{CO}_{2}$ emissions and GDP for GCC countries.

Saudi Arabia

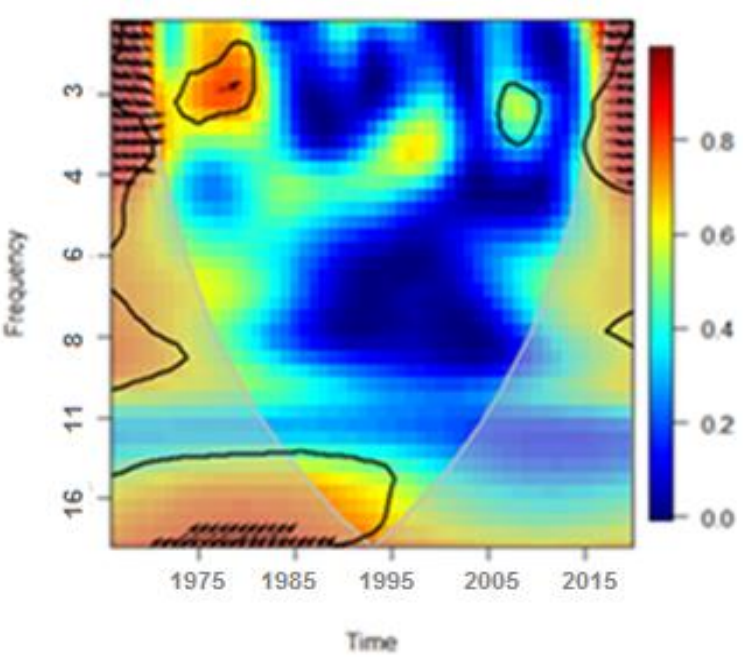

United Arab Emirates 


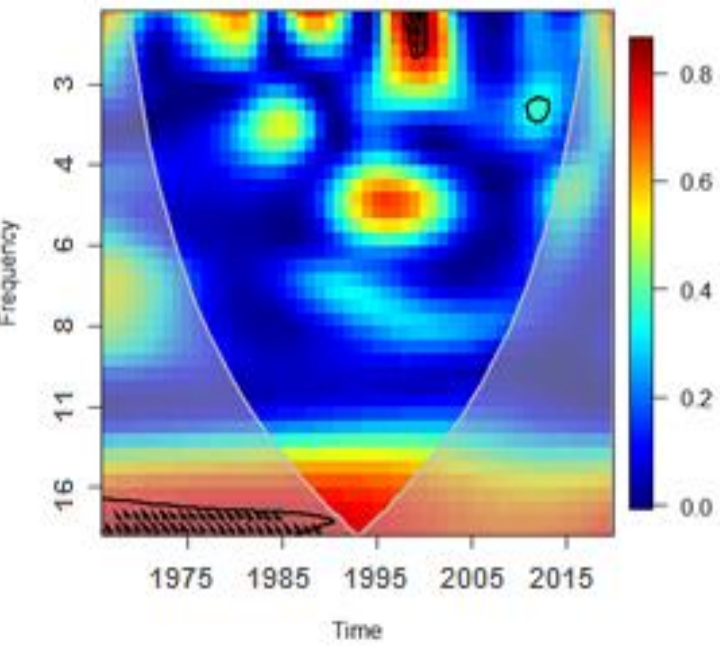

Qatar
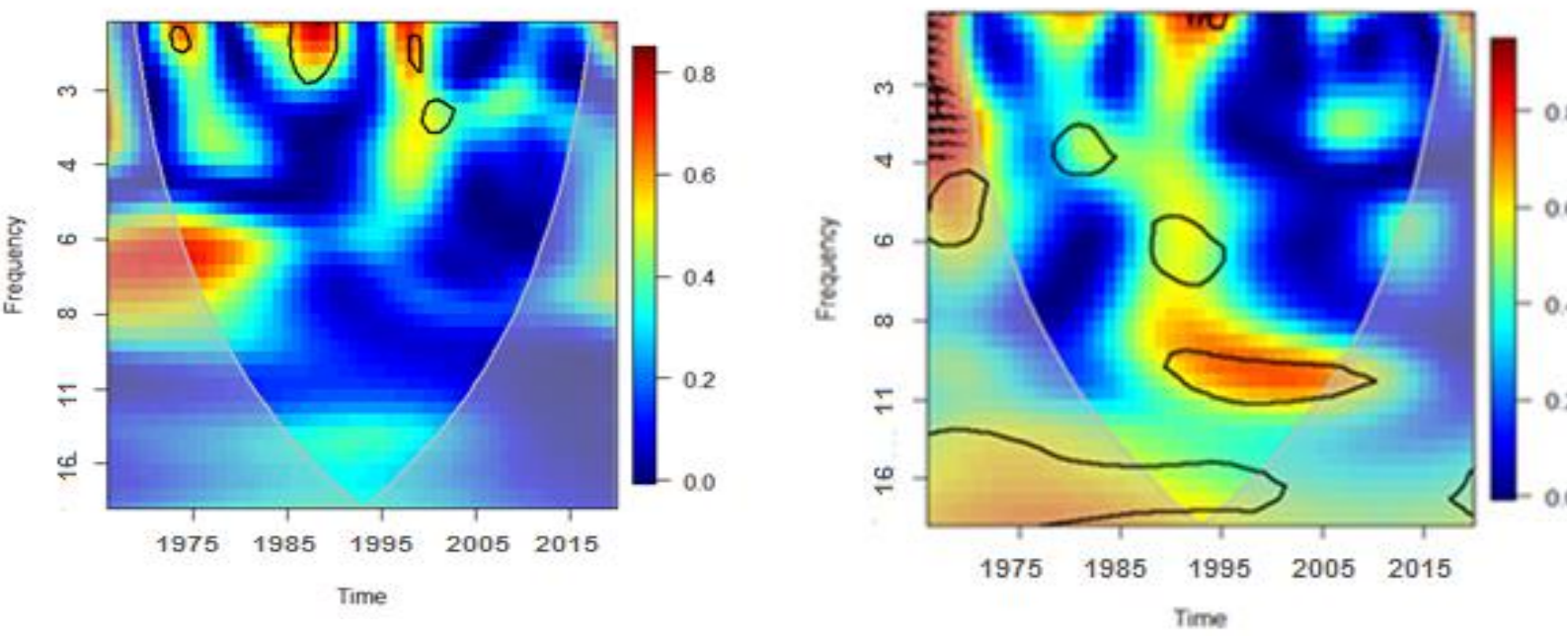

Oman

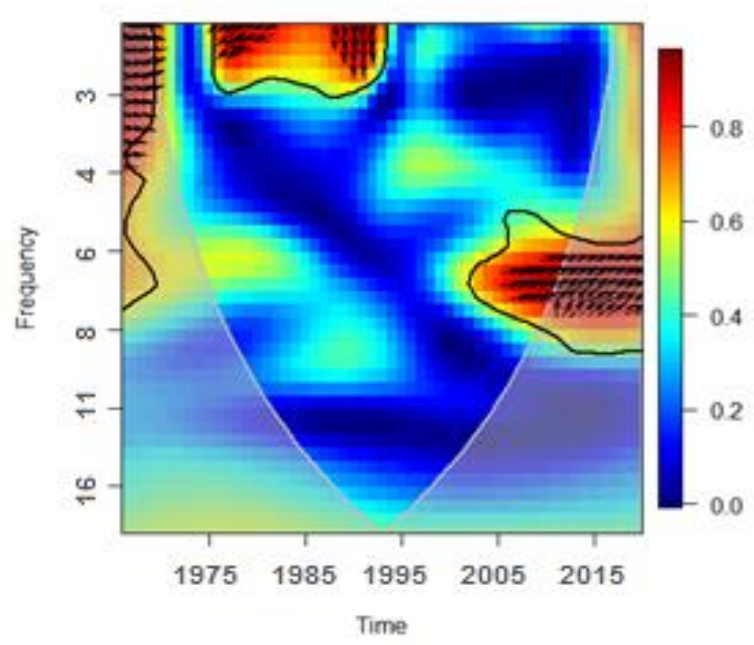

Bahrain

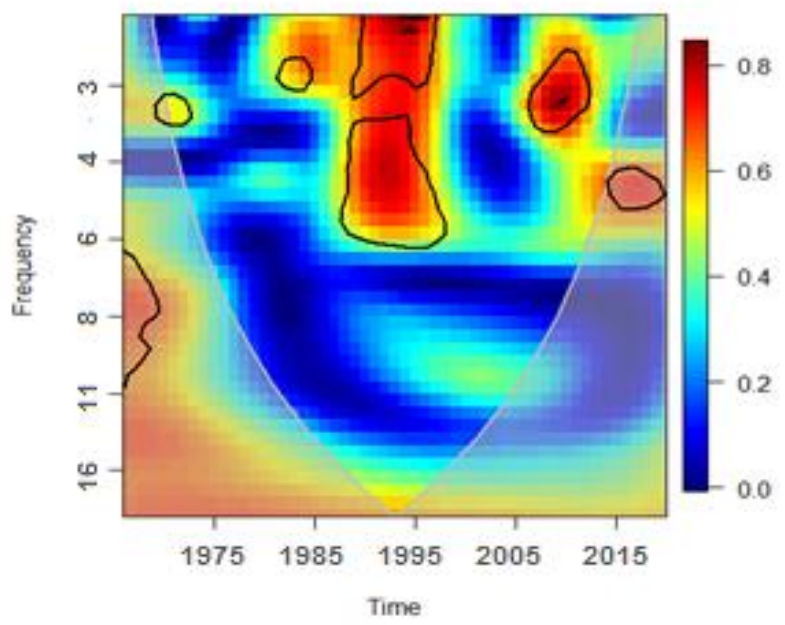


Figure 2 shows the results of the wavelet coherence analysis between $\mathrm{CO}_{2}$ emissions and electric power consumption for our panel. For Saudi Arabia, the results reveal a weak positive significant correlation between $\mathrm{CO}_{2}$ and $E P C$. For instance, in the period between 1965-1995, the rightward pointing arrows in the thick black shape area mostly support evidence of a positive relationship between GDP and $\mathrm{CO}_{2}$ at a high scale (16 years, long-run), as well as at a low scale (3-4 years). In the UAE, the overall results show a strong significant correlation over the whole study period, although it is sometimes positive or negative. During 1965-2005, the rightward pointing arrows in the thick black shape area mostly demonstrate the existence of a significant positive correlation between $\mathrm{CO}_{2}$ and $E P C$ at a high scale (8-16 years), and a positive correlation for the 1965-1980 period at a very low scale (2 years). For Qatar, the results highlight a strong negative significant correlation between $\mathrm{CO}_{2}$ and $E P C$ only at a high scale and in 1975-2015, the arrows were mostly leftward pointing in the thick black area. Regarding Kuwait, a correlation at a high scale (11-16 years) during the period 19651995 emerges. However, it is not significant. Regarding Oman, the analysis indicates a weak positive significant correlation between $\mathrm{CO}_{2}$ and $\mathrm{EPC}$ at both high as well as low scale over the period 1966-1995; instead, for the more recent years (2005-2019), a strong positive significant correlation at a low scale (3-4 years) is observed. Finally, regarding Bahrain, there is also a strong positive significant correlation at a mediumlow scale (3-7 years), for the 1965-1970, and a strong positive significant correlation at a low scale (3-4 years) during the period 1980-2000. Certainly, the analysis results prove that the increase in electric power consumption would lead to an increase in $\mathrm{CO}_{2}$ emissions in GCC countries, which will lead to a more degraded environment. This result shows that the environmental quality in GCC is strongly related the electric power consumption. Such a positive relationship between electric power consumption and $\mathrm{CO}_{2}$ pollution in GCC countries could be due to several simultaneous causes such as population significant growth rate, high GDP growth, relatively low prices of electricity and energy, hot climate, and the existence of inefficient technology. These results pertaining the positive correlation amid electric power consumption and $\mathrm{CO}_{2}$ emission are in line with those of Flores-Chamba et al. (2019) in the European Union; Wang et al. (2019) in the case of 186 countries; Zaidi et al. (2019) for APEC states.

Figure 2: Wavelet coherence between $\mathrm{CO}_{2}$ emissions and electric power consumption for GCC countries.

Saudi Arabia

United Arab Emirates 


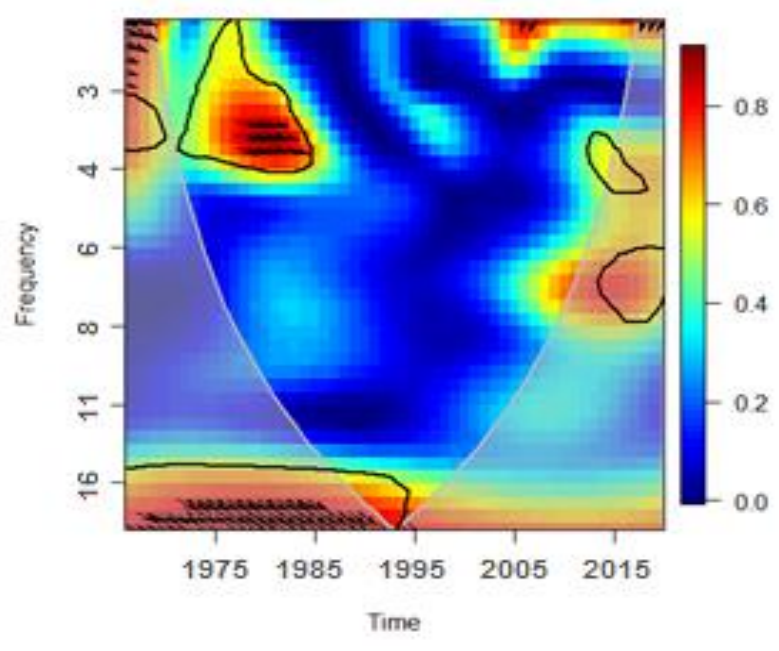

Qatar

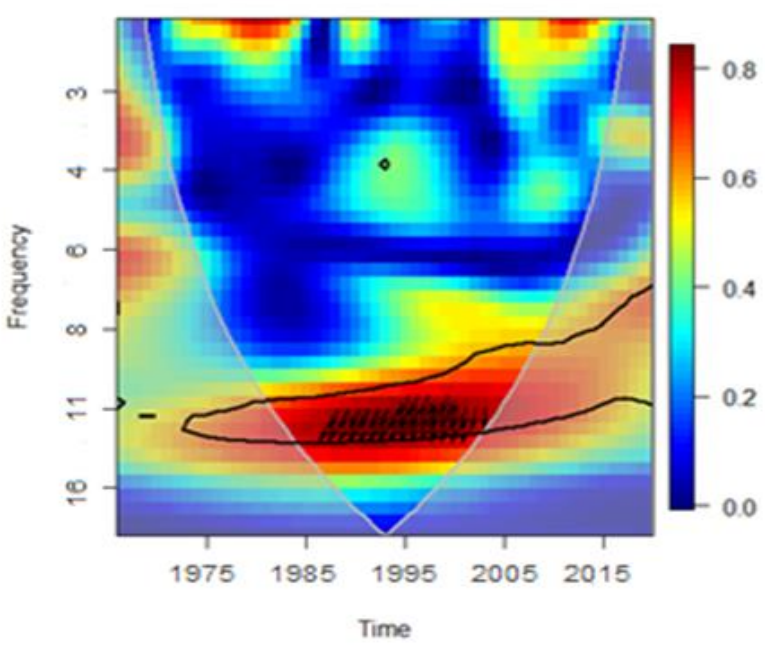

Oman

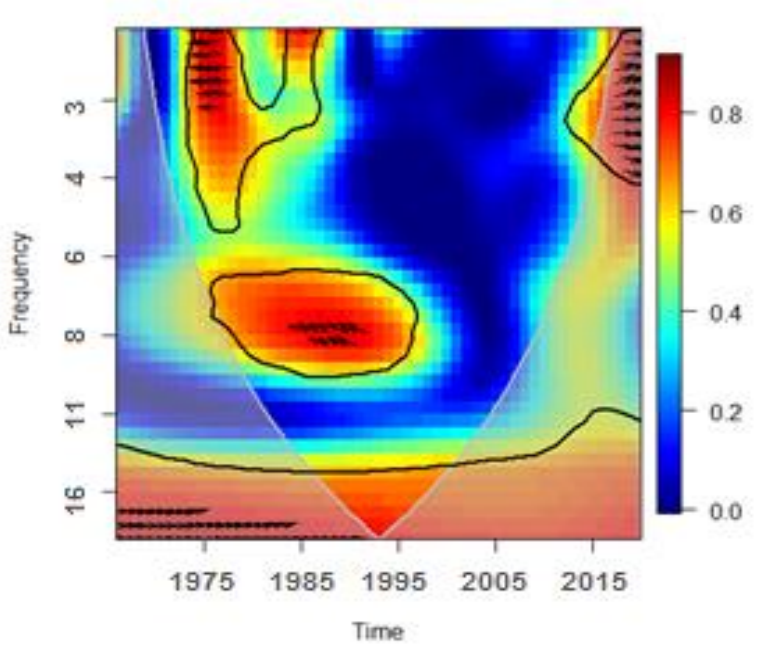

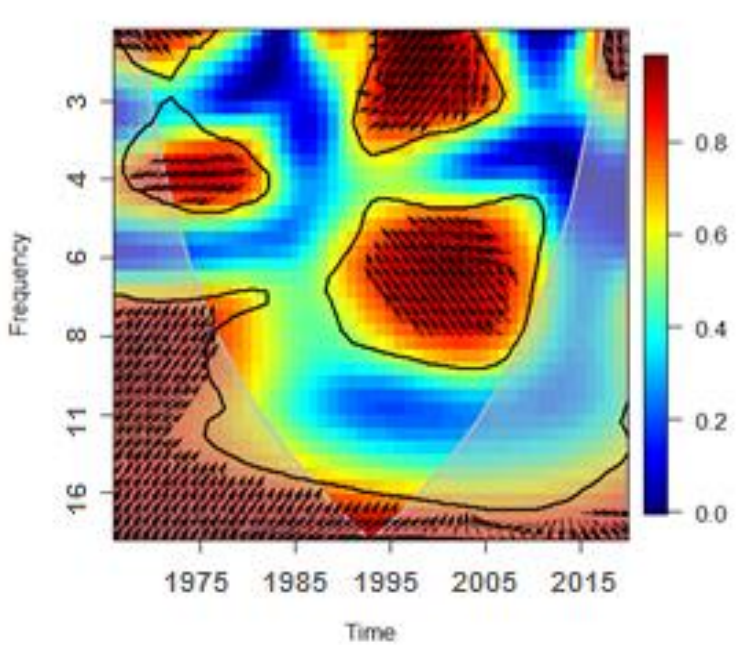

Kuwait

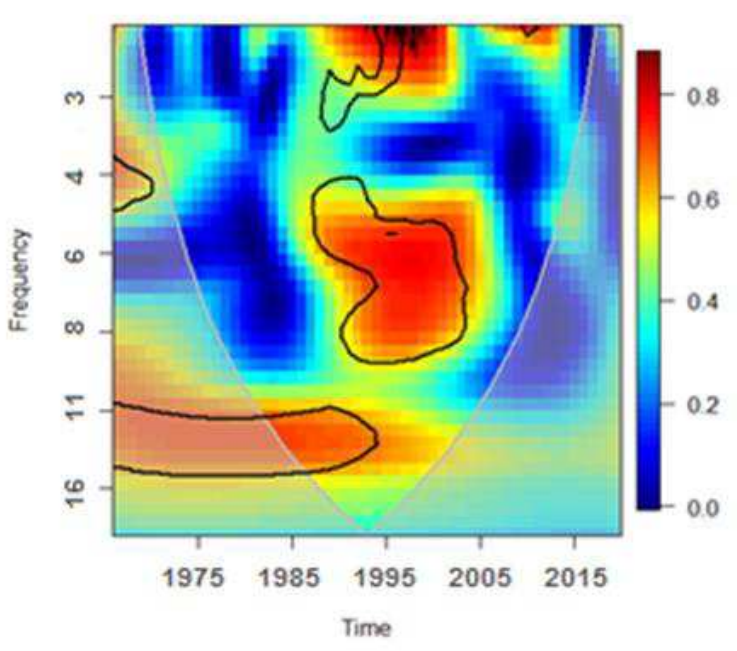

Bahrain

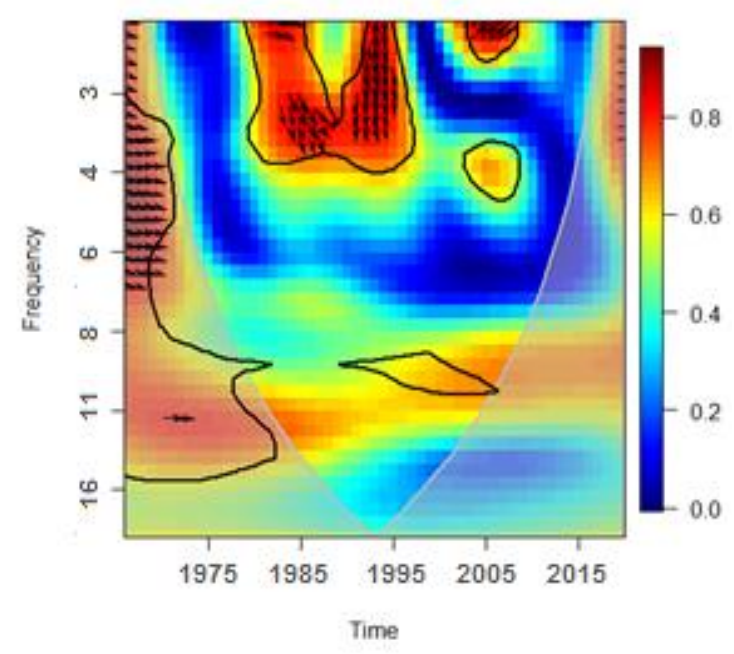


Figure 3 gives the results of the wavelet coherence between $\mathrm{CO}_{2}$ emissions and trade openness. Regarding Saudi Arabia, a weak positive correlation between the variables is registered, except for the early period 1970-1985, when a strong correlation at a low scale (3-4 years) emerges. For the UAE, the results are slightly different, since the rightward pointing arrows in the thick black shape area reveal evidence of a positive correlation between $\mathrm{CO}_{2}$ and $\mathrm{TO}$ at a medium-high scale (8-16 years) also at a low scale (3 years) over the period 1965-1985. Regarding Qatar, at a low scale (3 years) a significant positive correlation over the period between 1965-1975 is found, and the same results are shown at a high scale (11-12 years) for the 1975-2005 years. The results for Kuwait were mixed. In fact, during the period 1965-2019, the leftward pointing arrows in the thick black shape area show the existence of a strong negative significant correlation between these two variables at a high scale (12-16 years) and the same results for the period 1985-2005 at low scale (3-4 years), while a strong positive correlation at a medium scale (5-8 years) for the 1985-2010 period. A very strong negative significant correlation between $\mathrm{CO}_{2}$ and $\mathrm{TO}$ at a high scale (11-16 years) over the study period emerges for Oman and a positive correlation over the period 19651985. While during the period 2000-2010 at a low scale, the leftward pointing arrows in the thick black shape area indicate the existence of a strong negative significant correlation. With regard to Bahrain, the results indicate a strong positive significant correlation at a high scale (16 years) in the years 1965-1995, as well as a strong positive significant correlation at a low scale (3-4 years) in the 2005-2015 years.

The analysis results regarding the relationship between $T O$ and $\mathrm{CO}_{2}$ emissions in the GCC countries came mixed. For instance, in Saudi Arabia, Qatar, UAE and, Bahrain a positive relationship emerges. Hence, an increase in international trade leads to an increase in the environmental pollution in these countries. The positive result could be due to a heavy reliance on using fuel and other natural resources in the trade process, and the existent of polluting industries like the oil industry in these economies are among the biggest exporting oil in the world. These results are in line with those of Saidi and Mbarek (2017) applied to 19 emerging countries, and Oh and Bhuyan (2018) for the case of Bangladesh. For Kuwait and Oman $T O$, there is evidence of a negative effect on $\mathrm{CO}_{2}$ emissions over some period while positive over another, however, the effect was mostly negative. Indisputably, the negative effect of trade openness on $\mathrm{CO}_{2}$ emissions in these countries improves environmental quality. Such a negative link between $T O$ and $\mathrm{CO}_{2}$ emission supports the results of Saud et al. (2019) in the case of Belt and Road Initiative and Afridi et al. (2019) for the SAARC region.

Figure 3: Wavelet coherence between $\mathrm{CO}_{2}$ emissions and trade openness for GCC countries.

Saudi Arabia

United Arab Emirates 


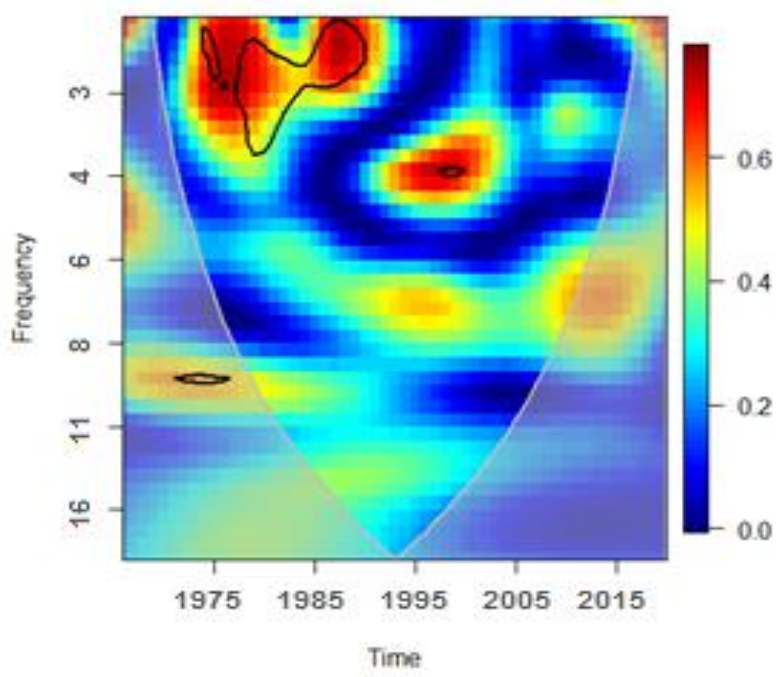

Qatar

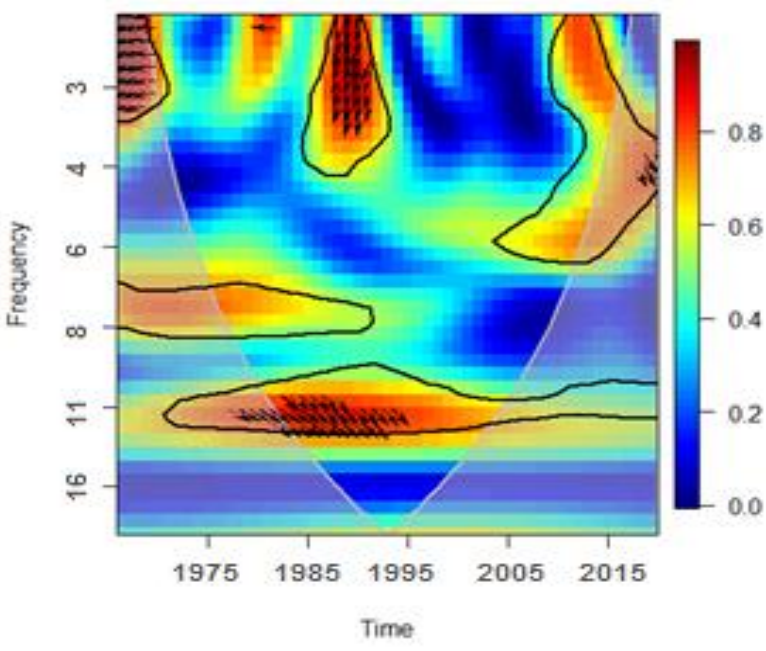

Oman

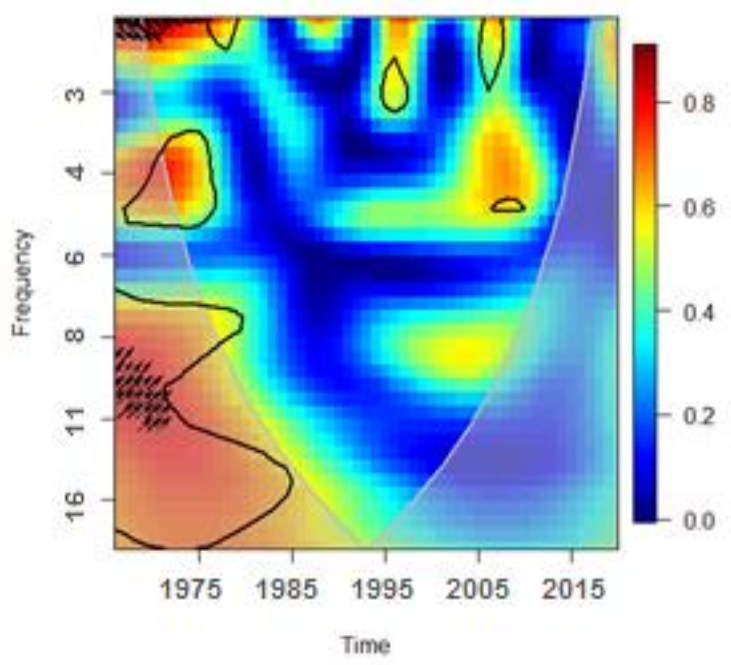

Kuwait

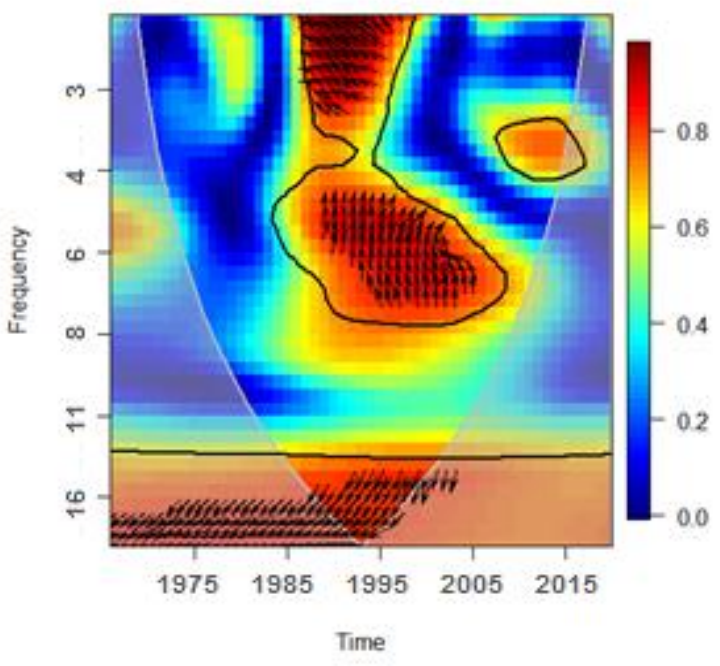

Bahrain 

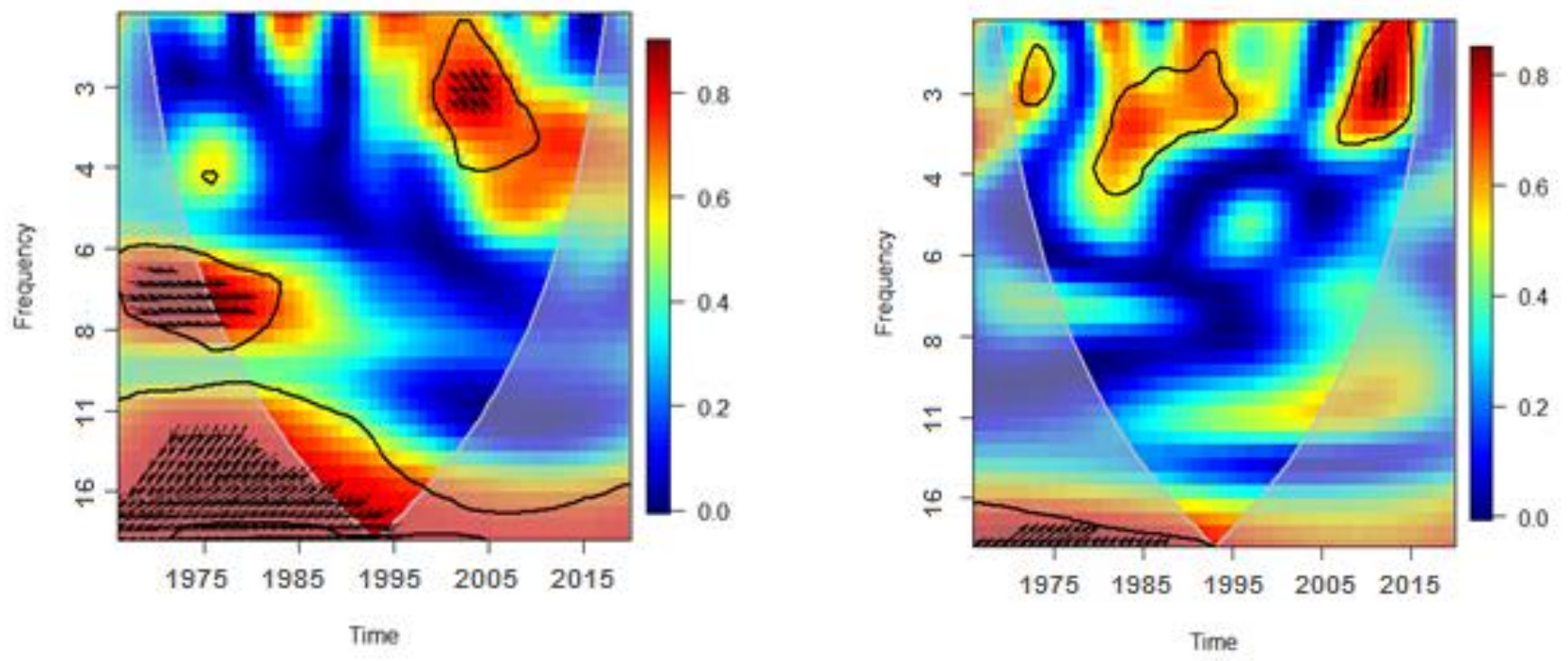

Finally, in Figure 4, results of the wavelet coherence between $\mathrm{CO}_{2}$ emissions and urbanization rate are presented. In the case of Saudi Arabia, a strong positive significant correlation emerges both at high and low scale. At a high scale (12-16 years) over the period 1965-2019, the results show a strong positive correlation, where the arrows in the thick black shape area are rightward pointing, while the results of medium and low scales show a strong positive significant correlation only during the 1965-1985 and 2010-2019 periods. As for the UAE, the rightward pointing arrows in the thick black shape area confirmed evidence of a positive correlation between these two variables at a medium scale (8-12 years) and at a low scale (3 years) in 1965-1980. With regard to Qatar, a significant positive correlation is found at a low scale (3 years) in the period 1965-1970. In the case of Kuwait, leftward pointing arrows in the thick black shape area indicate the existence of a strong negative significant correlation in the 1965-1985 period, at both low and high scales. Regarding Oman, the analysis indicates a strong positive significant correlation at both high and low scale over the period 1965-1975. For Bahrain, a strong positive significant correlation at a high scale (16 years) emerges during the years 1965-2019 and a strong positive significant correlation at medium and low scale over the periods 1965-1985 and 2015-2019.

The above-mentioned results of wavelet coherence analysis between urbanization and $\mathrm{CO}_{2}$ emissions highlight that urbanization mostly have a positive and statistically significant effect on $\mathrm{CO}_{2}$ emissions in GCC countries over the study period. According to Parikh and Shukla (1995) urbanization process is a part of the economic cycle. Hence, such results are not surprising, and theoretical debates prove it. Urbanization activities require much construction and development because it will be more desirable for people to move to more modern parts of the country. Such development leads to a huge environmental burden to any country since these projects would not be accomplished without using fuel and other natural resources. Another explanation for the positive relationship between urbanization and $\mathrm{CO}_{2}$ emissions in GCC countries could be related to what distinguishes these countries regarding the oil industry. GCC countries are among the biggest oil producers worldwide, and their economies are highly 
dependent on oil revenues. Thus, the oil industry strongly affects urban planning because of the large number of people who are currently employed in this industry and the labor force emigrants from rural to urban areas (Mahmood et al., 2020). This finding supports the ones of Tamura et al. (2018), Ali et al. (2019), and Alvarado et al. (2018), but varies from those of Asane-Otoo (2015), and Sun et al. (2018).

Figure 4: Wavelet coherence between $\mathrm{CO}_{2}$ emissions and urbanization for GCC countries.

Saudi Arabia

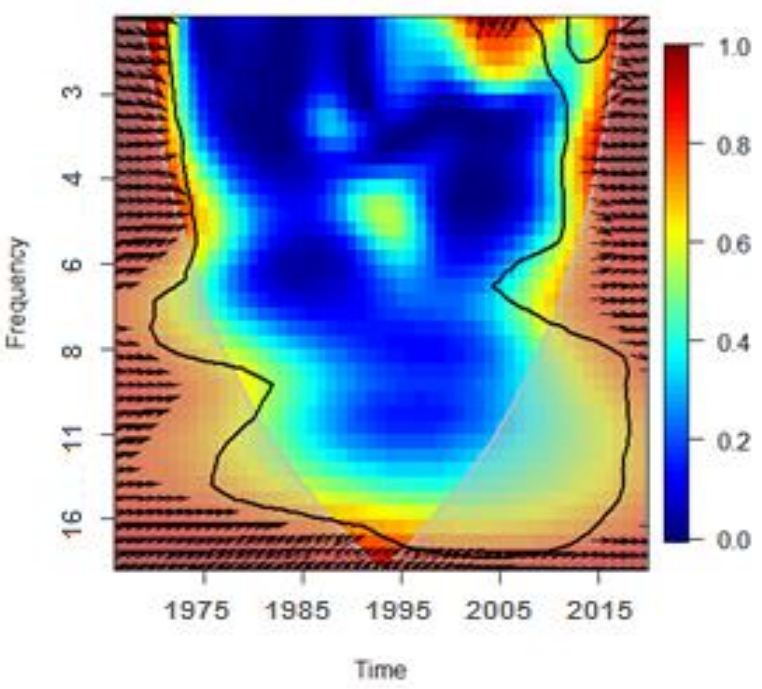

Qatar

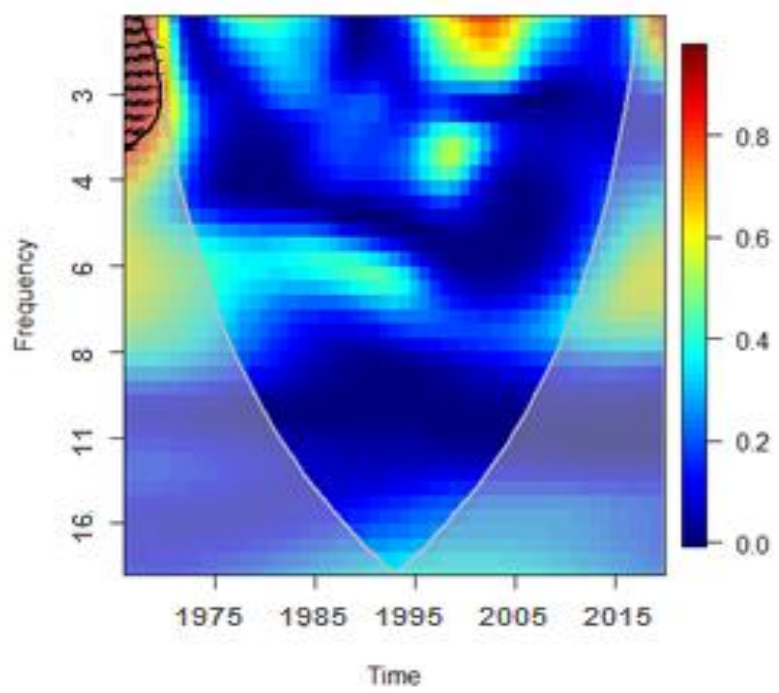

Oman
United Arab Emirates

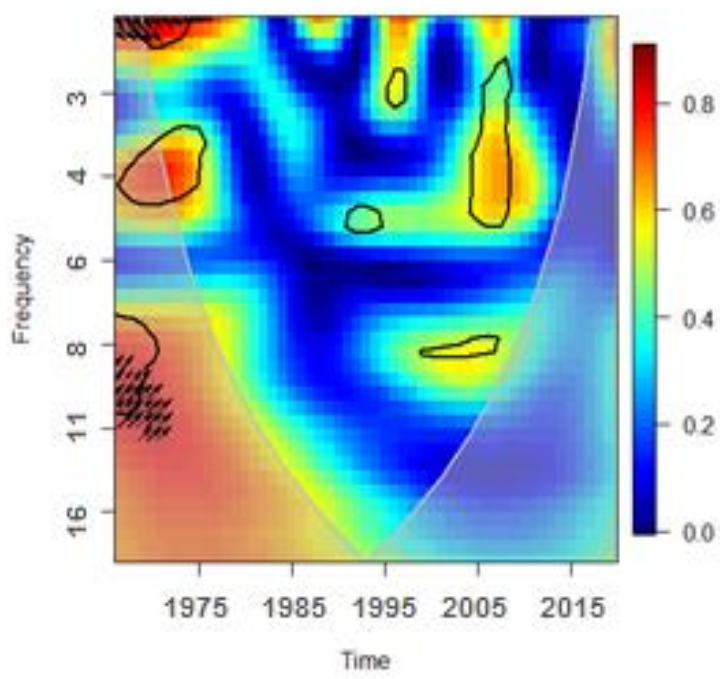

Kuwait

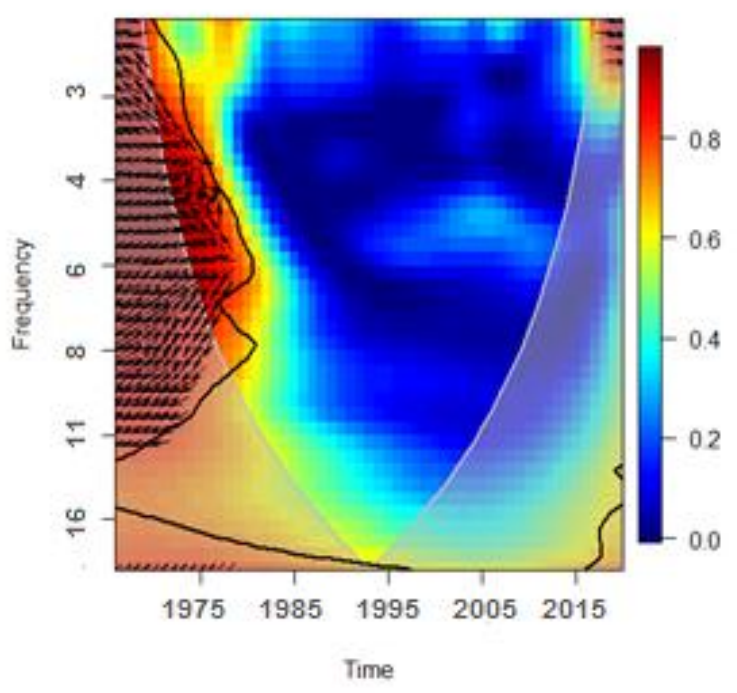

Bahrain 

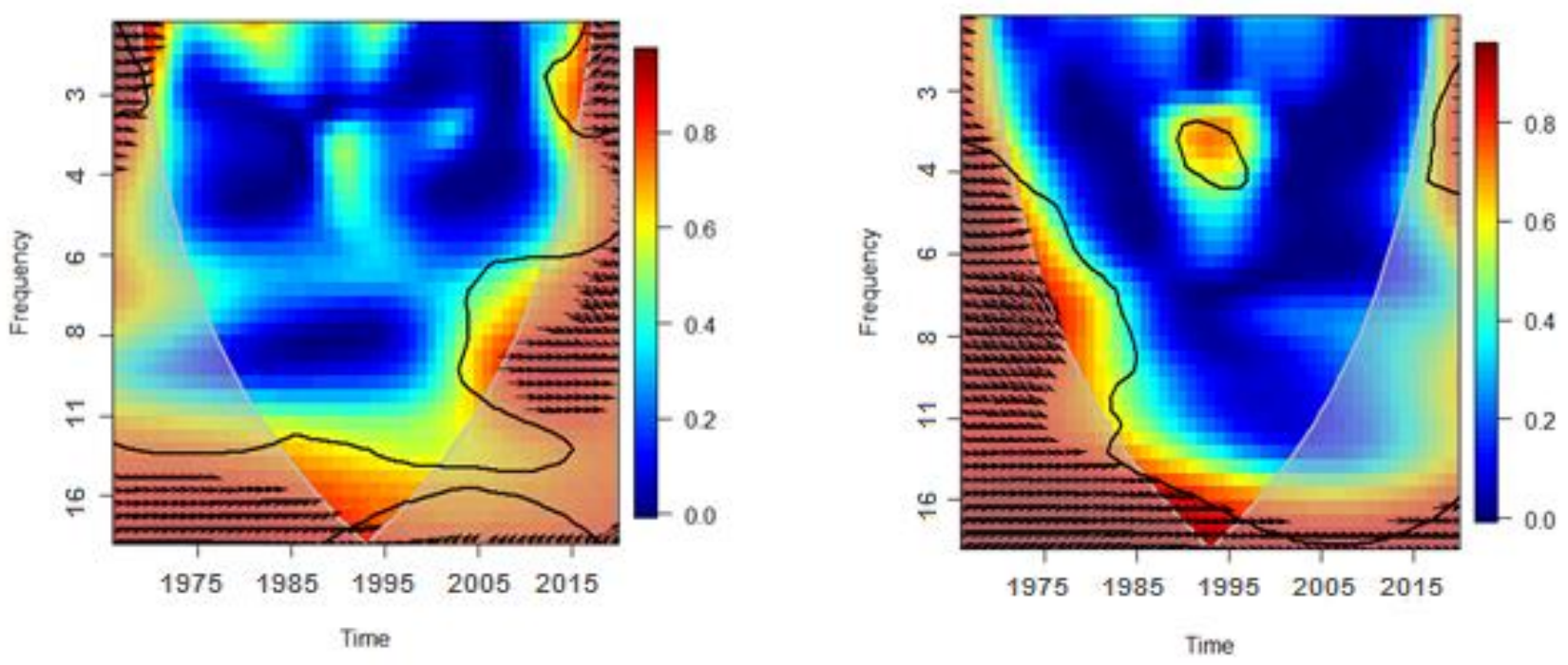

In conclusion, $E P C$ is the one that has the strongest correlation with $\mathrm{CO}_{2}$ upon the four independent variables analyzed (as shown in Figure 2). In a nutshell, EPC and $\mathrm{CO}_{2}$ are linked and in phase in the GCC sample when observing data from 1965 to 2019. On the other hand, the correlation between $\mathrm{CO}_{2}$ and $\mathrm{TO}$ is weak. Comparing these insights with the most relevant and recent literature, our results echo those of Salahuddin et al. (2015). Using FMOLS, DOLS and DFE, the authors supported the existence of a one-way link between electricity consumption and carbon emissions for GCC countries. In contrast, they shed light on a bidirectional relationship between economic and environmental indicators. Later, such results got updated in Salahuddin et al. (2018) for the specific case of Kuwait using VECLM and GC. Our findings are in line with a wide range of time-series causality assessments on this topic and which unanimously stressed the existence of underlying correlation forces among energy, economic and environmental indicators in the GCC area. See notably the early investigations from Alkhathlan and Javid (2013) for Saudi Arabia, Farhani et al. (2013) for 11 MENA countries; Omri (2013) for 14 MENA countries, Ozcan (2013) for 12 MENA countries; and more recently, Asif et al. (2015) for GCC countries; Magazzino et al. (2016a) for 10 MENA countries; Magazzino et al. (2016b) for 6 GCC countries; Bekhet et al. (2017) for GCC countries; and Magazzino and Cerulli (2019) for 17 MENA countries; and Magazzino and Schneider (2020) for Israel.

Nonetheless, one should mention that the present results contradict those of Hamdi and Sbia (2014a) since the authors failed to reveal the presence of a significant link between energy use and economic growth using a VECM approach to the 1980-2009 period in GCC countries. Similarly, our wavelet estimates conflict with the ARDL outcomes of Sari and Soytas (2009) as they concluded no substantial relationship between energy use and GDP, and among GDP and carbon emissions trends in five OPEC countries. Lastly, our findings are in line with the GCC-based evidence of Zmami and Ben-Salha (2020), Alkathery and Chaudhuri (2021), and Majeed et al. (2021), who emphasized that the nature of the resources exploited to generate power does matter in determining emissions trends in this area and should thus be at the heart of future policy regulations. Especially, Baydoun and Aga (2021) claimed evidence of 
a long-run association between energy consumption, financial development, economic growth, and $\mathrm{CO}_{2}$ emissions in GCC countries. Results drawn from a CS-ARDL model concurred to underline that economic growth and energy consumption adversely affect the region's sustainability path. Looking beyond correlation evidence, Qader et al. (2021) further connect with our conclusions. They attempted to identify which methodology, among neural network time series nonlinear autoregressive, Gaussian Process Regression and Holt's methods, performs the most reliable $\mathrm{CO}_{2}$ emission forecasting for Bahrain. For a clearer understanding, we have presented a summary of wavelet coherence overall findings in Table 4.

Table 4. Summary of wavelet coherence overall findings for GCC countries.

\begin{tabular}{|c|c|c|c|c|c|c|}
\hline & Saudi Arabia & UAE & Qatar & Kuwait & Oman & Bahrain \\
\hline $\begin{array}{c}\mathrm{CO}_{2} \mathrm{vs} \\
\mathrm{GDP}\end{array}$ & $\begin{array}{c}\text { Weakly posi- } \\
\text { tive and signif- } \\
\text { icant }\end{array}$ & $\begin{array}{c}\text { Weakly posi- } \\
\text { tive but insig- } \\
\text { nificant }\end{array}$ & $\begin{array}{c}\text { Weakly } \\
\text { positive } \\
\text { and signif- } \\
\text { icant }\end{array}$ & $\begin{array}{l}\text { Moderate } \\
\text { positive } \\
\text { and signif- } \\
\text { icant }\end{array}$ & $\begin{array}{l}\text { Weakly } \\
\text { positive } \\
\text { and sig- } \\
\text { nificant }\end{array}$ & $\begin{array}{l}\text { Weakly } \\
\text { but un- } \\
\text { clear }\end{array}$ \\
\hline $\begin{array}{c}\mathrm{CO}_{2} \mathrm{vs} \\
\mathrm{EPC}\end{array}$ & $\begin{array}{l}\text { Weakly posi- } \\
\text { tive and signif- } \\
\text { icant }\end{array}$ & $\begin{array}{l}\text { Strongly posi- } \\
\text { tive/negative } \\
\text { and significant }\end{array}$ & $\begin{array}{c}\text { Strongly } \\
\text { negative } \\
\text { and signif- } \\
\text { icant }\end{array}$ & $\begin{array}{l}\text { Insignifi- } \\
\text { cant }\end{array}$ & $\begin{array}{l}\text { Weakly } \\
\text { positive } \\
\text { and sig- } \\
\text { nificant }\end{array}$ & $\begin{array}{l}\text { Strongly } \\
\text { positive } \\
\text { and sig- } \\
\text { nificant }\end{array}$ \\
\hline $\mathrm{CO}_{2}$ vs TO & $\begin{array}{l}\text { Weakly posi- } \\
\text { tive/negative } \\
\text { and significant }\end{array}$ & $\begin{array}{l}\text { Weakly posi- } \\
\text { tive but un- } \\
\text { clear }\end{array}$ & $\begin{array}{c}\text { Weakly } \\
\text { positive } \\
\text { and signif- } \\
\text { icant }\end{array}$ & $\begin{array}{c}\text { Mixed } \\
\text { (positive } \\
\text { and nega- } \\
\text { tive) re- } \\
\text { sults }\end{array}$ & $\begin{array}{l}\text { Negative } \\
\text { and sig- } \\
\text { nificant }\end{array}$ & $\begin{array}{l}\text { Strongly } \\
\text { positive } \\
\text { and sig- } \\
\text { nificant }\end{array}$ \\
\hline $\begin{array}{c}\mathrm{CO}_{2} \text { vs } \\
\mathrm{URB}\end{array}$ & $\begin{array}{c}\text { Strongly posi- } \\
\text { tive and signif- } \\
\text { icant }\end{array}$ & $\begin{array}{l}\text { Weakly posi- } \\
\text { tive but insig- } \\
\text { nificant }\end{array}$ & $\begin{array}{l}\text { Weak pos- } \\
\text { itive but } \\
\text { insignifi- } \\
\text { cant }\end{array}$ & $\begin{array}{c}\text { Mixed } \\
\text { (positive } \\
\text { and nega- } \\
\text { tive) re- } \\
\text { sults }\end{array}$ & $\begin{array}{l}\text { Strongly } \\
\text { negative } \\
\text { and sig- } \\
\text { nificant }\end{array}$ & $\begin{array}{l}\text { Strongly } \\
\text { positive } \\
\text { and sig- } \\
\text { nificant }\end{array}$ \\
\hline
\end{tabular}

Notes: our elaborations.

\section{Concluding Remarks and Policy Implications}

This paper investigates the correlating association between electricity consumption, $\mathrm{CO}_{2}$ emissions, economic growth, urbanization, and trade openness for six Gulf Cooperation Council (GCC) countries using data covering the 1965-2019 period. In contrast to traditional time series approaches, our empirical strategy uses the wavelet analysis on the frequency domain, thought to complement the time-series econometric procedures reported on this topic.

Provided at the country level, the results present far-reaching policy recommendations whose applications may directly benefit environmental planning. In Saudi Arabia, the wavelet findings support the existence of a weak positive and significant correlation between $\mathrm{CO}_{2}$ and GDP, which is consistent with the existing literature. Regarding the UAE, evidence exhibits a weak positive correlation between GDP and carbon emissions, which turns insignificant when looking at the whole period. In Qatar and Bahrain, estimates indicate the presence of a weak and unclear relationship, indi- 
cating that the nature of this nexus is inconclusive. For Kuwait, however, wavelet findings provide evidence of a positive and significant correlation between electricity use and $\mathrm{CO}_{2}$ at a low scale.

In contrast, a weak positive correlation is depicted for Saudi Arabia. For Oman and Qatar, empirical results highlight the presence of a positive and statistically significant association between $\mathrm{CO}_{2}$ emissions and urbanization rate over the period between 1965-1970. For Bahrain, the results reveal the existence of a strong positive and significant correlation at high scale in the years 1965-2019, and a strong positive and significant correlation at medium and low scales over the periods 1965-1985 and 20152019, consistent with the recent conclusions derived from Shahbaz et al. (2020) and Al-Radaydeh et al. (2021). In general, one sees that the empirical relationship between $\mathrm{CO}_{2}$ and GDP emerges here as weak and unclear. Results are mostly positive and significant at low and medium scales (3-8 years) and insignificant at the high scale. The most positive effect of GDP on $\mathrm{CO}_{2}$ emission in GCC countries is linked to the fact that these economies are highly dependent on oil revenues. In addition, the transition policy to use sustainable and renewable energy techniques may explain the fuzzy nature of this evidence. Increasing oil prices helps boost growth output, resulting in higher average household revenues. According to the findings, rising energy use could worsen environmental quality by raising $\mathrm{CO}_{2}$ emissions in the country.

These findings contradict our findings, explaining the positive response of $\mathrm{CO} 2$ to increased economic development. The conclusions of this study have significant policy implications for the GCC, not just from an environmental standpoint but also in terms of financial resource allocation for future planning. The GCC countries have recently adopted a more proactive approach to environmental challenges on the international, national, and regional levels. However, the remodel initiatives, on the other hand, have not yet resulted in the formulation of consistent environmental modernization policies (Bekhet at. Al, 2017). Notwithstanding their limitations, our findings are thought to bring high information value for different parties, helping government, policy makers, investors, and research departments, while developing comprehensive sustainable energy policies in the Gulf region.

The energy efficiency targets of the GCC countries for forthcoming decades are highly insightful. Shorty, while Bahrain aims to reduce electricity consumption by $6 \%$ by 2025 , Kuwait plans to enhance the efficiency along the power generation process by $5 \%$ in 2020 and lower energy consumption by $30 \%$ in 2030. Also, Oman seeks to lower greenhouse gas emissions by $2 \%$ in 2030, whereas Qatar's main goal is to explicitly diminish per capita electricity and water consumption by $8 \%$ and $15 \%$ by 2022 , respectively. Nonetheless, Saudi Arabia also projects to limit the growth of power needs by $8 \%$ and $14 \%$ by 2021 , respectively. This corroborates the track followed by the UAE as this latter set the objective to mitigate the electricity demand by $30 \%$ (in Dubai) in 2030. Being the core of solutions, improving energy efficiency for corporates and individuals is central. If adequately implemented, energy efficiency measures are expected to rise by $40 \%$ in the area by 2050 , which would induce associated carbon emissions savings of approximately 70\% (IRENA GCC, 2019).

Linking these insights to national strategies provides fruitful information. Saudi Arabia, for instance, displays the longest and most elaborate planning heritage among 
the GCC countries. Its Long-Term Strategy, covering the years 2005-24, was developed in 2004 to raise the national economy to advanced countries, implying doubling per capita income. It was founded in response to a number of issues, including the need to provide productive employment for Saudi nationals while also improving the quality of life. There is also a strong desire to expand the role of non-oil output in the economy and diversify and expand the economy. Second, the UAE's objective is to become one of the best places in the world to do business, with a clear path to long-term development that is less dependent on oil in the future. This entails expanding new strategic sectors in order to channel synergies into industries and services where long-term competitive advantage can be gained. To take a step forward, the government fosters energy sector innovation, research, and development to strengthen the regulatory framework for developing high-value-added sectors and improve the long-term outlook. Third, Bahrain Vision 2030 aims to boost private sector productivity and establish a climate that encourages entrepreneurship and innovation, resulting in knowledgebased and high-value-added businesses and economic activities. By situating investment projects, can help to bring new technological innovation in energy pathways. Fourth, through economic expansion, diversification, and GDP growth, Kuwait State Vision 2035 plan aims to transform Kuwait into regional commerce and financial hub for the northern Gulf. It also encourages private sector investment, which can help to strengthen state-led growth. Fifthly, the goal of Oman Vision 2030 is to 'provide favourable conditions for economic take-off,' which entails diversification by expanding non-oil production. It also intends to make significant changes to the national economy's structure by broadening the production base, expanding the private sector's position in the economy, and improving human resources. The diversification plan to liberalize foreign ownership policies is one way to improve the investment environment. Finally, Qatar Vision 2030 includes precise plans for individual projects and activities and economic and institutional growth goals. Finally, Qatar Vision 2030 includes precise plans for individual projects and activities, economic and institutional improvements, and long-term development goals. Three overarching principles will lead to economic development: competent economic management, responsible oil and gas exploitation, and appropriate economic diversification. (National financial strategies of the GCC countries, Hvidt, 2013).

From these insights, country-specific policy measures can be elaborated with direct applications in the GCC region. Above all, the financial and services may play a leading role in the Bahrain economy, together with fossil fuels. As a matter of fact, services already cover $59.2 \%$ of total GDP in 2020 and are yet expected to meet a promising path (WDI, 2020). By contrast, Kuwait's plan focuses on infrastructure investments, transportation, and (silk city) business hub. Oman's vision by 2020-2025 calls for economic diversification, increased private activity and human resource development, industrial fertilizer, water desalination, and tourism. This latter element already represents $48.1 \%$ of the aggregate value-added generated in 2020, equivalent to $\$ 32$ billion of current US\$ (WDI, 2020). Regarding Saudi Arabia, the government's vision 2030 set in 2016 focuses on developing new industries and business through massive public investments. It is thus not surprising that the introduction of Value Added Tax (VAT) in the GCC was first achieved in Saudi Arabia and UAE to in January 2018. But to do so, Saudi Arabia will have to diversify its economy further, starting by lowering the 
contribution of oil to national GDP (oil rents represented 24.2\% of GDP in 2020) and triggering the emergence of the services sector (which covered $25.4 \%$ of GDP in 2020), more likely to embed high value-added, human capital formations, and technologies (WDI, 2020). Tightly linked to this view, Qatar's national strategy for 2030 also aims to create a more diversified economy, reducing thus its dependence on oil revenues in the long run. Besides, the government calls for a more efficient natural resources management, including a growing place dedicated to renewables in the future power supply. Still, the share of low-carbon and alternative energy resources is insufficient in the total energy consumed, mostly dominated by oil and natural gas with $26.85 \%$ and $73.09 \%$ of total energy consumed in 2019, respectively (BP Statistical Review of World Energy, 2020). Major green energy expansions are expected to deploy further renewables whose coverage is lower than $1 \%$ of total energy consumed. The government should catch the opportunity represented by solar relatively higher natural endowment (Jahangiri et al., 2020). Overall, the UAE vision 2021, UAE energy strategy 2050, UAE green growth strategy, and UAE future strategy centennials plan 2071 converge to a central goal: positioning UAE as a regional hub for research, inducing immediate improvements for the tourism sector. As a matter of fact, Foreign Direct Investments (FDI - net inflows) recorded a 26\% growth compared to 2005 but still covers only $3.3 \%$ of GDP in 2020 (WDI, 2020).

Undoubtedly, suggesting energy and economic strategies in the current warming context emphasizes the close connections of this topic to climate change. While it has emerged as a major threat for biodiversity, coastal populations, water shortages and food security, global warming is expected to create heterogeneous effects across countries, regions and sectors (Stern, 2006). Our illustrative GCC case is highly likely that extreme weather shocks may affect these economies shortly (Abdulrahman, 2020). Even if major reforms are implemented today, the relationship between GHG emissions and temperature is neither immediate nor linear, suggesting that the benefits from present policies may emerge after a time lag of several decades. In the light of today's knowledge, countries located in the middle east are expected to experience an acceleration of temperature shocks, which might translate into real damages through three channels. First, increasing the frequency of high temperature events will create a sharp rise in electricity needs, notably for cooling purposes (Ahmed et al., 2012; McFarland et al., 2015; Rivers and Shaffer, 2020). Knowing that most of these countries intensively rely on the combustion of fossil fuels to generate power, questions are ongoing on how they can avoid the release of additional pollutants to adapt to a warming environment, which may further alter the climate dynamic. Second, major losses are expected on agricultural production, with a direct effect on household incomes. Further inputs (technologies, water, pesticides) will be necessary to compensate for the land's productivity losses and mitigate the emergence of a poverty trap in rural areas (Agnolucci et al., 2020; Liu et al., 2020; Warsame et al., 2020). Third and finally, health is likely to become a major outcome of rising temperature, notably because it has been shown that long exposure to a critical temperature create damages that policymakers can no longer ignore (Anenberg et al., 2020; Mousavi et al., 2020; Margolis, 2021). All these adaptation strategies are costly and require important investments to cover their fixed capital costs. The growth pattern may solve only one side of the problem by mitigating today's emissions (Victor, 2012). However, the debate is ongoing on 
how reducing wealth may fill the need for funding, infrastructures and facilities for climate adaptation purposes (Perkings, 2019). One more step but a long mile to go.

\section{Limitations and Caveats}

Notwithstanding its relevance, this paper suffers from limitations and caveats based on which prospects for future research can be proposed.

Above all, despite being a power tool on the frequency domain, the wavelet coherence approach does not provide real causality results. Instead, it draws correlating evidence that limits the scope of policy recommendations that can be generated after that. Hence, we suggest future studies rely on time-series econometric tools to stress the existence, nature, and direction of causalities among variables. Newly developed quantile regression and cointegration models would confirm the above results and extend them by perhaps reconciling the conflicting conclusions reported so far on this matter. In addition, insights-based macroeconomic indicators are relevant but broad. In this paper, we admit that aggregate data measures fail to offer a precise picture of the GCC energy and environmental issues. Instead, information is lost, and channels are gathered in a fuzzy framework. If data availability allows that, future studies should conduct sectoral analyses and help identify which sectors drive atmospheric pollution and how to channel low energy-intensive sectors that may potentially trigger it. Going one step further, firm-level evidence should complement our insights and help policymakers determine how medium and high-tech industries operate as technological diffusers and low-carbon energy enablers across sectors. There is a need to understand further the channels operating among energy, economic and environmental indicators, and top-down research (from macroeconomic to household levels) is necessary. Lastly, despite its incipient nature, the use of Machine Learning methodologies derived from Artificial Intelligence has demonstrated power capacities on related topics (Magazzino et al., 2020a; 2020b; 2020c, 2021). Future papers should look at incorporating such innovative data testing methods within a time-series framework and coupled them with time-series econometric procedures.

\section{Author Declarations}

Funding: there has been no financial support for this work that could have influenced its outcome.

Conflicts of interest: we confirmed that there are no known conflicts of interest associated with this publication.

Availability of data and material/ Data availability: all data are available upon request.

Code availability: we employed the $\mathrm{R}$ data programming software for data analysis.

\section{Authors Contribution:}

Ali Matar: Performed the conceptualization, investigation, data curation, supervision, and original draft preparation, Reviewing. 
Zeeshan Fareed: Performed data curation, methodology, and software.

Cosimo Magazzino: Performed methodology, validation, supervision, and writing reviewing and editing.

Mahmoud Al-Rdaydeh: Analysed the section of results analysis and discussion and software.

Nicolas Schneider: Visualization, Data curation, Writing - Original draft preparation. Note: All authors read and approved the final manuscript.

We further confirm that the order of authors listed in the manuscript has been approved by all of us. We understand that the Corresponding Author is the sole contact for the Editorial process (including Editorial Manager and direct communications with the office). He is responsible for communicating with the other authors about progress, submissions of revisions and final approval of proofs. We confirm that we have provided a current, correct email address which is accessible by the Corresponding Author.

\section{Acknowledgements}

Comments from the Editor and the anonymous referees are gratefully acknowledged. However, the usual disclaimer applies.

\section{References}

Abdulrahman, S.A., 2020. Water shortage in GCC countries: Transferring water from Iraqi Kurdistan Region. International Journal of Environmental Studies, 77, 2, 191-207.

Acaravci, A., Ozturk, I., 2010. On the relationship between energy consumption, $\mathrm{CO}_{2}$ emissions and economic growth in Europe. Energy, 35, 5412-5420.

Afridi MA, Kehelwalatenna S, Naseem I, Tahir M (2019) Per capita income, trade openness, urbanization, energy consumption, and CO2 emissions: an empirical study on the SAARC Region. Environ Sci Pollut Res 26(29), 29978-29990.

Agnolucci, P., Rapti, C., Alexander, P., De Lipsis, V., Holland, R.A., Eigenbrod, F., Ekins, P., 2020. Impacts of rising temperatures and farm management practices on global yields of 18 crops. Nature Food, 1, 9, 562-571.

Ahmed, T., Muttaqi, K.M., Agalgaonkar, A.P., 2012. Climate change impacts on electricity demand in the State of New South Wales, Australia. Applied Energy, 98, 376-383.

Al-Badi, A., AlMubarak, I., 2019. Growing energy demand in the GCC countries. Arab Journal of Basic and Applied Sciences, 26, 1, 488-496.

Ali R, Bakhsh K, Yasin MA (2019) Impact of urbanization on CO2 emissions in emerging economy: evidence from Pakistan. Sustain Cities Soc 48:101553.

Al-Iriani, M.A., 2006. Energy-GDP relationship revisited: an example from GCC countries using panel causality. Energy Policy, 34, 17, 3342-3350.

Alkathery, M.A., Chaudhuri, K., 2021. Co-movement between oil price, $\mathrm{CO}_{2}$ emission, renewable energy and energy equities: Evidence from GCC countries. Journal of Environmental Management, 297, 113350.

AlKhars, M., Miah, F., Qudrat-Ullah, H., Kayal, A., 2020. A systematic review of the relationship between energy consumption and economic growth in GCC countries. Sustainability, 12, 9, 3845.

Alkhathlan, K., Javid, M., 2013. Energy consumption, carbon emissions and economic growth in Saudi Arabia: An aggregate and disaggregate analysis. Energy Policy, 62, 1525-1532.

Al-Mulali, U., 2012. Exploring the bi-directional long run relationship between urbanization, energy consumption and carbon dioxide emission. Energy, 46, 156-67.

Al-mulali, U., 2012. Factors affecting $\mathrm{CO}_{2}$ emission in the Middle East: A panel data analysis, Energy, 
44, 564-569.

Al-Mulali, U., Che Sab, C.N.B., 2018. Electricity consumption, CO2 emission, and economic growth in the Middle East. Energy Sources, Part B: Economics, Planning, and Policy, 13, 5, 257-263.

Al-Mulali, U., Ozturk, I., 2015. The effect of energy consumption, urbanization, trade openness, industrial output, and the political stability on the environmental degradation in the MENA (Middle East and North African) region. Energy, 84, 382-389.

Al-Mulali, U., Tang, C.F., 2013. Investigating the validity of pollution haven hypothesis in the gulf cooperation council (GCC) countries. Energy Policy, 60, 813-819.

Aloui, C., Hkiri, B., 2014. Co-movements of GCC emerging stock markets: new evidence from wavelet coherence analysis. Economic Modelling, 36, 421-431.

Al-Rawashdeh, R., Jaradat, A.Q., Al-Shboul, M., 2014. Air pollution and economic growth in MENA countries: testing EKC hypothesis. Environmental Research, Engineering and Management, 70, 4, 54-65.

Al-Rdaydeh, M., Schneider, N., Matar, A., 2021. Examining the linkages among electricity consumption, income and environmental pollution in Saudi Arabia: from a spectral wavelet analysis to the Granger Causality test. International Journal of Environmental Studies, 1-29.

Al-Saleh, Y.M., Vidican, G., Natarajan, L., Theeyattuparampil, V.V., 2012. Carbon capture, utilisation and storage scenarios for the Gulf Cooperation Council region: A Delphi-based foresight study. Futures, 44, 1, 105-115.

Alvarado R, Ponce P, Criollo, Córdova K, Khan MK (2018) Environmental degradation and real per capita output: new evidence at the global level grouping countries by income levels. J Clean Prod 189:13-20.

Anenberg, S.C., Haines, S., Wang, E., Nassikas, N., Kinney, P.L., 2020. Synergistic health effects of air pollution, temperature, and pollen exposure: a systematic review of epidemiological evidence. Environmental Health, 19, 1, 1-19.

Apergis, N., Salim, R., 2015. Renewable energy consumption and unemployment: evidence from a sample of 80 countries and nonlinear estimates. Applied Economics, 47, 52, 5614-5633.

Arouri, M, Yousef, A, Mhenni, H, Rault, C., 2012b. Empirical Analysis of the EKC Hypothesis for Sulfur Dioxide Emissions in Selected Middle East and North African Countries. Journal of Energy and Development, 37, 1-2, 207-226.

Arouri, M., Youssef, A., Mhenni, H., Rault, C., 2012a. Energy consumption, economic growth and $\mathrm{CO}_{2}$ emissions in Middle East and North African countries. Energy Policy, 45, 342-9.

Asane-Otoo E (2015) Carbon footprint and emission determinants in Africa. Energy 82:426-435.

Asif, M., Sharma, R.B., Adow, A.H.E., 2015. An empirical investigation of the relationship between economic growth, urbanization, energy consumption, and $\mathrm{CO} 2$ emission in GCC countries: a panel data analysis. Asian Social Science, 11, 21, 270.

Aslan, A., Apergis, N., Yildirim, S., 2014. Causality between energy consumption and GDP in the US: evidence from wavelet analysis. Frontiers in Energy, 8, 1, 18.

Basarir, A., Arman, H., 2014. Sustainable development and environmental Kuznets Curve in GCC countries. In Proceedings of the 13th International Conference on Environmental Science and Technology.

Basdas, U. (2012). Interaction between MENA stock markets: a comovement wavelet analysis. Available at SSRN 2333774.

Baydoun, H., Aga, M., 2021. The Effect of Energy Consumption and Economic Growth on Environmental Sustainability in the GCC Countries: Does Financial Development Matter?. Energies, 14, $18,5897$.

Bekhet, H.A., Matar, A., Yasmin, T., 2017. CO2 emissions, energy consumption, economic growth, and financial development in GCC countries: Dynamic simultaneous equation models. Renewable and Sustainable Energy Reviews, 70, 117-132.

Bella, G., Massidda, C., Mattana, P., 2014. The relationship among CO2 emissions, electricity power consumption and GDP in OECD countries. Journal of Policy Modeling, 36, 6, 970-985.

Benhmad, F., 2012. Modeling nonlinear Granger causality between the oil price and US dollar: a wavelet-based approach. Economic Modelling, 29, 4, 1505-1514.

Benhmad, F., 2013. Dynamic cyclical comovements between oil prices and US GDP: a wavelet perspective. Energy Policy, 57, 141-151. 
British Petroleum (BP), 2020. Statistical Review of World Energy. Available at: <https:/www.bp.com/en/global/corporate/energy-economics/statistical-review-of-world-energy.html>.

Cifter, A., \& Ozun, A. (2007). Multi-scale causality between energy consumption and GNP in emerging markets: evidence from Turkey. Online at https://mpra.ub.uni-muenchen.de/2483/.

Cowan, W N., Chang, T., Inglesi-Lotz, R., Gupta, R., 2014. The nexus of electricity consumption, economic growth and $\mathrm{CO} 2$ emissions in the BRICS countries. Energy Policy, 66, 359-368.

Dinda, S., Coondoo, D., 2006. Income and emission: a panel data-based cointegration analysis. Ecological Economics, 57, 167-181.

Dumitrescu EI, Hurlin C., 2012. Testing for Granger non-causality in heterogeneous panels. Econ Model, 29(4):1450-60.

Ehigiamusoe KU, Lean HH (2019) Effects of energy consumption, economic growth, and financial development on carbon emissions: evidence from heterogeneous income groups. Environ Sci Pollut Res 26(22):22611-22624.

Engle, R.F., Granger, C.W.J., 1987. Cointegration and error correction: representation, estimation, and testing. Econometrica, 55, 2, 251-276.

Ertugrul, H.M., Cetin, M., Seker, F., Dogan, E., 2016. The impact of trade openness on global carbon dioxide emissions: evidence from the top ten emitters among developing countries. Ecological Indicators, 67, 543-555.

Farhani, S., Shahbaz, M., Arouri, M.E.H., 2013. Panel analysis of CO2 emissions, GDP, energy consumption, trade openness and urbanization for MENA countries. Online at https://mpra.ub.unimuenchen.de/49258/.

Flores-Chamba J, López-Sánchez M, Ponce P, Guerrero-Riofrío P, Álvarez-García J (2019) Economic and spatial determinants of energy consumption in the European Union. Energies 12(21):4118.

Galeotti, M., Lanza, A., Pauli, F., 2006. Reassessing the environmental Kuznets curve for CO2 emissions: a robustness exercise. Ecological Economics, 57, 1, 152-163.

Germanwatch., 2017. The climate change performance index 2017. Bonn: Author. Available:https://www.global2000.at/sites/global/files/Climate\%20Change\%20Performance\%20Index\%202017\%20-\%20embargoed.pdf

Grinsted, A.,Moore, J.C., Jevrejeva, S., 2004. Application of the crosswavelet transformand wavelet coherence to geophysical time series. Nonlinear Process. Geophys. 11, 561-566.

Grossman, G.M., Krueger, A.B., 1995. Economic growth and the environment. Quarterly Journal of Economics, 110, 2, 353-377.

Ha, J., Tan, P. P., Goh, K. L., 2018. Linear and nonlinear causal relationship between energy consumption and economic growth in China: New evidence based on wavelet analysis. PloS ONE, 13, 5.

Hamdi H, Sbia R., 2014. The dynamic relationship between CO2 emissions, energy usage and Growth in Gulf Cooperation Council (GCC) countries: an aggregated analysis. Economie Appliquée, 67, 161-182.

Hamdi, H., Sbia, R., 2014. Dynamic relationship between electricity consumption and economic growth in a small open economy: the case of Bahrain. Research Directorate at the Ministry of Finance.

Hamdi, H., Sbia, R., Shahbaz, M., 2014. The nexus between electricity consumption and economic growth in Bahrain. Economic Modelling, 38, 227-37.

Hertog, S., Luciani, G., 2009. Energy and sustainability policies in the GCC. The Center for the Study of Global Governance. Kuwait programme on Development. Governance and Globalization in the Gulf States. Available at : http://dro.dur.ac.uk/7178/1/7178.pdf

Hossain AN, Hasanuzzaman S (2013) Remittances and investment nexus in Bangladesh: an ARDL bounds testing approach. Int Rev Econ 60(4):387-407.

Huang, B.N., Hwang, M.J., Yang, C.W., 2008. Causal relationship between energy consumption and GDP growth revisited: a dynamic panel data approach. Ecological Economics, 67, 41-54.

Hvidt, M., 2013. Economic diversification in GCC countries: Past record and future trends. Retrieved from: 〈http://eprints.lse.ac.uk/55252/〉

Intergovernmental Panel on Climate Change (IPCC), 2021. Climate Change widespread, rapid and intensifying. Available at: <https://www.ipcc.ch/2021/08/09/ar6-wg1-20210809-pr/>.

International Energy Agency (IEA), 2020. IEA Energy Outlook - Region - Middle East. Available at: $<$ https://www.iea.org/regions/middle-east>. 
IPCC, 2014. Climate Change 2014: Synthesis Report. in: Contribution of Working Groups I, II and III to the Fifth Assessment Report of the Intergovernmental Panel on Climate Change, IPCC, Geneva, Switzerland.

IRENA, GCC, report of 2019 available at : https://www.irena.org/-/media/Files/IRENA/Agency/Publication/2019/Jan/IRENA_Market_Analysis_GCC_2019.pdf. Accessed in 7 July 2020.

Jahangiri, M., Shamsabadi, A.A., Mostafaeipour, A., Rezaei, M., Yousefi, Y., Pomares, L. M., 2020. Using fuzzy MCDM technique to find the best location in Qatar for exploiting wind and solar energy to generate hydrogen and electricity. International Journal of Hydrogen Energy, 45, 27, 1386213875.

Jaunky, V., 2011. The CO2 Emissions-Income Nexus: Evidence from Rich Countries. Energy Policy, $39,3,1228-1240$.

Kahouli, B., 2018. The causality link between energy electricity consumption, CO2 emissions, R\&D stocks and economic growth in Mediterranean countries (MCs). Energy, 145, 388-399.

Kraft, J., Kraft, A., 1978. On the relationship between energy and GNP. The Journal of Energy Development, 3, 401-403.

Kristjanpoller, W., Sierra, A., Scavia, J., 2018. Dynamic co-movements between energy consumption and economic growth. A panel data and wavelet perspective. Energy Economics, 72, 640-649.

Kuwait Institute for Scientific Research, 2012. Kuwait Energy Outlook. Kuwait City, Kuwait, 2019.

Lau, L.C., Tan, K.T., Lee, K.T., Mohamed, A.R., 2009. A comparative study of the energy policies in Japan and Malaysia in fulfilling their nations' obligations towards the Kyoto protocol. Energy Policy, 37, 4771-4780.

Lean, H.H., Smyth, R., 2010. CO2 emissions, electricity consumption and output in ASEAN. Applied Energy, 87, 6, 1858-1864.

Lee, C.C., Chang, C.P., 2007b. Energy consumption and GDP revisited: a panel analysis of developed and developing countries. Energy Economics, 29, 1206-1223.

Lee, S., Kim, J., Chong, W.K., 2016. The causes of the municipal solid waste and the greenhouse gas emissions from the waste sector in the United States. Waste Management, 56, 593-599.

Liu, H., Lei, M., Zhang, N., Du, G., 2019. The causal nexus between energy consumption, carbon emissions and economic growth: New evidence from China, India and G7 countries using convergent cross mapping. PloS One, 14, 5, e0217319.

Liu, M., Xu, X., Jiang, Y., Huang, Q., Huo, Z., Liu, L., Huang, G., 2020. Responses of crop growth and water productivity to climate change and agricultural water-saving in arid region. Science of The Total Environment, 703, 134621.

Liu, Y., \& Hao, Y. (2018). The dynamic links between CO2 emissions, energy consumption and economic development in the countries along "the Belt and Road". Science of the total Environment, 645, 674-683.

Liu, Y., Hao, Y., 2018. The dynamic links between CO2 emissions, energy consumption and economic development in the countries along "the Belt and Road". Science of the total Environment, 645, 674683.

Magazzino, C., 2016a. $\mathrm{CO}_{2}$ emissions, economic growth, and energy use in the Middle East countries: A panel VAR approach. Energy Sources, Part B: Economics, Planning, and Policy, 11, 10, 960968.

Magazzino, C., 2016b. The relationship between real GDP, $\mathrm{CO}_{2}$ emissions, and energy use in the GCC countries: A time series approach. Cogent Economics \& Finance, $4,1$.

Magazzino, C., 2017. Stationarity of electricity series in MENA countries. The Electricity Journal, 30, $10,16-22$.

Magazzino, C., Cerulli, G., 2019. The Determinants of $\mathrm{CO}_{2}$ Emissions in MENA Countries: A Responsiveness Scores Approach. International Journal of Sustainable Development \& World Ecology, 26, 6, 522-534.

Magazzino, C., Mele, M., Schneider, N., 2020a. The relationship between municipal solid waste and greenhouse gas emissions: Evidence from Switzerland. Waste Management, 113, 508-520.

Magazzino, C., Mele, M., Schneider, N., 2020b. The relationship between air pollution and COVID19-related deaths: an application to three French cities. Applied Energy, 279, 115835.

Magazzino, C., Mele, M., Schneider, N., Shahbaz, M., 2021. Can biomass energy curtail environmental pollution? A quantum model approach to Germany. Journal of Environmental Management, 287, 
112293.

Magazzino, C., Mele, M., Schneider, N., Vallet, G., 2020c. The relationship between nuclear energy consumption and economic growth: evidence from Switzerland. Environmental Research Letters, 15, 9, 0940a5.

Magazzino, C., Schneider, N., 2020. The causal relationship between primary energy consumption and economic growth in Israel: a multivariate approach. International Review of Environmental and Resource Economics, 14, 4, 417-491.

Mahadevan, R., Asafu-Adjaye, J., 2007. Energy consumption, economic growth and prices: a reassessment using panel VECM for developed and developing countries. Energy Policy, 35, 4, 2481-2490.

Mahmood, H., Alkhateeb, T.T.Y., Furqan, M., 2020. Oil sector and $\mathrm{CO}_{2}$ emissions in Saudi Arabia: asymmetry analysis. Palgrave Communications, 6(1), 1-10.

Majeed, A., Wang, L., Zhang, X., Kirikkaleli, D., 2021. Modeling the dynamic links among natural resources, economic globalization, disaggregated energy consumption, and environmental quality: Fresh evidence from GCC economies. Resources Policy, 73, 102204.

Margolis, H.G., 2021. Heat waves and rising temperatures: human health impacts and the determinants of vulnerability. In Climate Change and Global Public Health (pp. 123-161). Humana, Cham.

Matar, A., 2016. A Dynamic Equilibrium Relationship between Foreign Direct Investment, Electrical Power Consumption and Gross Domestic Product in Jordan. Jordan Journal of Economic Sciences.

Matar, A., 2020. Does electricity consumption impacting financial development? Wavelet analysis. $F u$ ture Business Journal, 6, 1-9.

Matar, A., Bekhet, H.A., 2015. Causal interaction among electricity consumption, financial development, exports and economic growth in Jordan: Dynamic simultaneous equation models. International Journal of Energy Economics and Policy, 5, 4.

McFarland, J., Zhou, Y., Clarke, L., Sullivan, P., Colman, J., Jaglom, W. S., ... \& Creason, J., 2015. Impacts of rising air temperatures and emissions mitigation on electricity demand and supply in the United States: a multi-model comparison. Climatic Change, 131, 1, 111-125.

Mehrara, M., 2007. Energy consumption and economic growth: the case of oil exporting countries. Energy policy, 35, 5, 2939-2945.

Mousavi, A., Ardalan, A., Takian, A., Ostadtaghizadeh, A., Naddafi, K., \& Bavani, A. M., 2020. Climate change and health in Iran: a narrative review. Journal of Environmental Health Science and Engineering, 18, 1, 367-378.

Narayan, P, Narayan, S., 2010. Carbon dioxide emissions and economic growth: panel data evidence from developing countries. Energy Policy, 38, 1, 661-666.

Narayan, P.K., Popp, S., 2012. The energy-real GDP nexus revisited: empirical evidence from 93 countries. Economic Modelling, 29, 303-308.

Narayan, P.K., Smyth, R., 2009. Multivariate granger causality between electricity consumption, exports and GDP: evidence from a panel of Middle Eastern countries. Energy Policy, 37, 1, 229-236.

National Aeronautics and Space Administration (NASA), 2020. Global Climate Change - Vital Signs of the Planet. Available at: 〈https://climate.nasa.gov/>.

Njoke, M.L., Wu, Z., Tamba, J.G., 2019. Empirical Analysis of Electricity Consumption, CO2 Emissions and Economic Growth: Evidence from Cameroon. International Journal of Energy Economics and Policy, 9, 5, 63.

Omri, A., 2013. CO2 emissions, energy consumption and economic growth nexus in MENA countries: Evidence from simultaneous equations models. Energy economics, 40, 657-664.

Omri, A., Nguyen, D.K., 2014. On the determinants of renewable energy consumption: international evidence. Energy, 72, 554-560.

Osman, M., Gachino, G., Hoque, A., 2016. Electricity consumption and economic growth in the GCC countries: Panel data analysis. Energy Policy, 98, 318-327.

Osman, M., Gachino, G., Hoque, A., 2016. Electricity consumption and economic growth in the GCC countries: Panel data analysis. Energy Policy, 98, 318-327.

Ozcan, B., 2013. The nexus between carbon emissions, energy consumption and economic growth in Middle east countries: a panel data analysis. Energy Policy, 62, 1138-1147.

Ozturk, I., 2010. A literature survey on energy-growth nexus. Energy Policy, 38, 1, 340-349.

Ozturk, I., Acaravci, A., 2011. Electricity consumption and real GDP causality nexus: Evidence from ARDL bounds testing approach for 11 MENA countries. Applied Energy, 88, 8, 2885-2892. 
Parikh J, Shukla V (1995) Urbanization, energy use and greenhouse effects in economic development: results from a cross-national study of developing countries. Glob Environ Chang 5(2):87-103.

Perkins, P.E.E., 2019. Climate justice, commons, and degrowth. Ecological Economics, 160, 183-190.

Popp, A., Krause, M., Dietrich, J. P., Lotze-Campen, H., Leimbach, M., Beringer, T., \& Bauer, N. (2012). Additional CO2 emissions from land use change-forest conservation as a precondition for sustainable production of second generation bioenergy. Ecological Economics, 74, 64-70.

Priestley, M.B., 1965. Evolutionary spectra and non-stationary processes. Journal of the Royal Statistical Society: Series B (Methodological), 27, 2, 204-229.

Ramsey, J.B., Lampart, C., 1998. Decomposition of economic relationships by timescale using wavelets. Macroeconomic Dynamics, 2, 1, 49-71.

Reiche, D., 2010. Renewable Energy Policies in the Gulf countries: a case study of the carbon-neutral "Masdar City" in Abu Dhabi. Energy Policy, 38, 378-382.

Rivers, N., Shaffer, B., 2020. Stretching the Duck: How rising temperatures will change the level and shape of future electricity consumption. The Energy Journal, 41, 5.

Rua A (2010) Measuring comovement in the time-frequency space. J Macroecon 32(2):685-691.

Rua A, Nunes LC (2009) International comovement of stock market returns: a wavelet analysis. J Empir Finance ,16(4):632-639.

Saboori, B., Sapri, M., Baba, M., 2014. Economic growth, energy consumption and CO2 emissions in OECD (Organization of Economic Co-operation and Development)'s transport sector: A fully modified bi-directional relationship approach. Energy, 66, 1, 150-161.

Sadorsky, P., 2014. The effect of urbanization on CO2 emissions in emerging economies. Energy Economics, 41, 147-153.

Saidi, K., \& Mbarek, M. B. (2017). The impact of income, trade, urbanization, and financial development on CO 2 emissions in 19 emerging economies. Environmental Science and Pollution Research, 24(14), 12748-12757.

Salahuddin, M., Alam, K., Ozturk, I., Sohag, K., 2018. The effects of electricity consumption, economic growth, financial development and foreign direct investment on $\mathrm{CO} 2$ emissions in Kuwait. Renewable and Sustainable Energy Reviews, 81, 2002-2010.

Salahuddin, M., Gow, J., 2014. Economic growth, energy consumption and CO2 emissions in Gulf Cooperation Council countries. Energy, 73, 44-58.

Salahuddin, M., Gow, J., 2019. Effects of energy consumption and economic growth on environmental quality: evidence from Qatar. Environmental Science and Pollution Research, 26, 18, 18124-18142.

Salahuddin, M., Gow, J., Ozturk, I., 2015. Is the long-run relationship between economic growth, electricity consumption, carbon dioxide emissions and financial development in Gulf Cooperation Council Countries robust? Renewable and Sustainable Energy Reviews, 51, 317-326.

Sari, R., Soytas, U., 2009. Are global warming and economic growth compatible? Evidence from five OPEC countries?. Applied Energy, 86, 10, 1887-1893.

Saud S, Chen S, Haseeb A, Khan K, ImranM(2019) The nexus between financial development, income level, and environment in Central and Eastern European Countries: a perspective on Belt and Road Initiative. Environ Sci Pollut Res 26(16):16053-16075.

Seetanah, B., Sannassee, R.V., Fauzel, S., Soobaruth, Y., Giudici, G., Nguyen, A.P.H., 2019. Impact of economic and financial development on environmental degradation: evidence from small island developing states (SIDS). Emerg Mark Financ Trade, 55(2):308-322.

Selden, T.M., Song, D., 1994. Environmental quality and development: is there a Kuznets curve for air pollution emissions? Journal of Environmental Economics and Management, 27, 2, 147-162.

Shahbaz, M., Haouas, I., Sohag, K., Ozturk, I., 2020. The financial development-environmental degradation nexus in the United Arab Emirates: the importance of growth, globalization and structural breaks. Environmental Science and Pollution Research, 1-15.

Shahbaz, M., Uddin, G.S., Rehman, I.U., Imran, K., 2014. Industrialization, electricity consumption and $\mathrm{CO} 2$ emissions in Bangladesh. Renewable and Sustainable Energy Reviews, 31, 575-586.

Soytas, U., Sari, R., 2009. Energy consumption, economic growth and carbon emissions: challenges faced by an EU candidate member. Ecological Economics, 68, 1667-75.

Squalli, J., 2007. Electricity consumption and economic growth: bounds and causality analyses for OPEC members. Energy Economics, 29, 1192-1205.

Stern, D. I., Common, M. S., \& Barbier, E. B. (1996). Economic growth and environmental degradation: 
the environmental Kuznets curve and sustainable development. World development, 24(7), 11511160.

Stern, D.I., 2004. The rise and fall of the environmental Kuznets curve. World Development, 32, 8, 1419-1439.

Stern, N., 2006. Stern Review: The economics of climate change.

Tamura S, Iwamoto S, Tanaka T (2018) The impact of spatial population distribution patterns on CO2 emissions and infrastructure costs in a small Japanese town. Sustain Cities Soc 40:513-523.

Toda, H.Y., Yamamoto, T., (1995). Statistical inference in vector autoregressions with possibly integrated processes. Journal of Econometrics, 66, 1-2, 225-250.

Torrence, C., Compo, G.P., 1998. A practical guide to wavelet analysis. Bull. Am. Meteorol. Soc. 79, 61-78.

Victor, P.A., 2012. Growth, degrowth and climate change: A scenario analysis. Ecological Economics, 84, 206-212.

Wang Q, Su M, Li R, Ponce P (2019b) The effects of energy prices, urbanization and economic growth on energy consumption per capita in 186 countries. J Clean Prod 225:1017-1032.

Wang Y, Wang Y, Zhou J, Lu G. Energy consumption and economic growth in China: a multivariate causality test. Energy Policy, 2011;39:4399-406.

Warsame, A.A., Sheik-Ali, I.A., Ali, A.O., Sarkodie, S.A., 2021. Climate change and crop production nexus in Somalia: an empirical evidence from ARDL technique. Environmental Science and Pollution Research, 28, 16, 19838-19850.

World Bank, 2019. World Development Indicators. Washington, DC, USA. Last accessed at: < http://data.worldbank.org/data-catalog/world-development-indicators/World Bank-2019> on 03/03/20.

World Meteorological Organization (WMO), 2017. WMO greenhouse gas bulletin. The state of greenhouse gases in the atmosphere based on global observations through 2016.

World Meteorological Organization (WMO), 2018. WMO greenhouse gas bulletin. The state of greenhouse gases in the atmosphere based on global observations through 2017.

Yuhai, L., \& Peng, W. (2011). Energy Consumption, Carbon Dioxide Emission and Regional Economic Growth in the APEC Economies. Economic Review, 6, 109-129.

Zaidi SAH, Zafar MW, Shahbaz M, Hou F (2019) Dynamic linkages between globalization, financial development and carbon emissions: evidence from Asia Pacific Economic Cooperation countries. J Clean Prod 228:533-543.

Zhang, Y., Zhang, J., Yang, Z., \& Li, S. (2011). Regional differences in the factors that influence China's energy-related carbon emissions, and potential mitigation strategies. Energy Policy, 39(12), $7712-7718$.

$\mathrm{Zi}, \mathrm{C}$., Jie, W., Hong-Bo, C., 2016. $\mathrm{CO}_{2}$ emissions and urbanization correlation in China based on threshold analysis. Ecological Indicators, 61, 193-201.

Zmami, M., Ben-Salha, O., 2020. An empirical analysis of the determinants of $\mathrm{CO}_{2}$ emissions inGCC .countriesInternational Journal of Sustainable Development \& World Ecology, 27, 5, 469-480. 